\title{
Merchanting and Current Account Balances
}

Elisabeth Beusch, Barbara Döbeli, Andreas Fischer and Pınar Yeşin

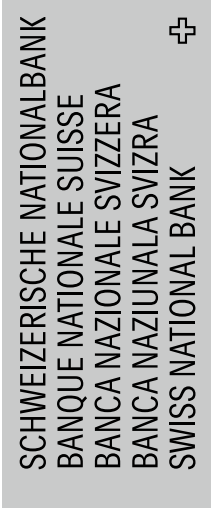

$$
\text { (2) }
$$


The views expressed in this paper are those of the author(s) and do not necessarily represent those of the Swiss National Bank. Working Papers describe research in progress. Their aim is to elicit comments and to further debate.

\section{Copyright ${ }^{\odot}$}

The Swiss National Bank (SNB) respects all third-party rights, in particular rights relating to works protected by copyright (information or data, wordings and depictions, to the extent that these are of an individual character). SNB publications containing a reference to a copyright ( $\odot$ Swiss National Bank/SNB, Zurich/year, or similar) may, under copyright law, only be used (reproduced, used via the internet, etc.) for non-commercial purposes and provided that the source is mentioned. Their use for commercial purposes is only permitted with the prior express consent of the SNB.

General information and data published without reference to a copyright may be used without mentioning the source.

To the extent that the information and data clearly derive from outside sources, the users of such information and data are obliged to respect any existing copyrights and to obtain the right of use from the relevant outside source themselves.

\section{Limitation of liability}

The SNB accepts no responsibility for any information it provides. Under no circumstances will it accept any liability for losses or damage which may result from the use of such information. This limitation of liability applies, in particular, to the topicality, accuracy, validity and availability of the information.

ISSN 1660-7716 (printed version)

ISSN 1660-7724 (online version)

๑ 2013 by Swiss National Bank, Börsenstrasse 15, P.0. Box, CH-8022 Zurich 


\title{
Merchanting and Current Account Balances*
}

\author{
Elisabeth Beusch, Barbara Döbeli, \\ Andreas Fischer ${ }^{\dagger}$ and Pınar Yeşin \\ Swiss National Bank, Boersenstrasse 15, PO Box, CH-8022 Zurich, Switzerland \\ April 2013
}

\begin{abstract}
Merchanting is goods trade that does not cross the border of the firm's country of residence. Merchanting grew strongly in the last decade in several small open economies, particularly in Finland, Ireland, Sweden, and Switzerland, and has become an important driver of these countries' current account. Because merchanting firms reinvest their earnings abroad to expand their international activities, this practice raises national savings in the home country without increasing domestic investment. This results in a significantly large current account surplus. To show the empirical links between merchanting and the current account balance, two exercises are performed in this paper using a sample of 53 countries during 1980-2011. The first exercise estimates the savings impact of merchanting countries in empirical models of the medium-term current account and shows that the presence of merchanting activity in a country indeed increases its current account balance by $3 \%$ on average. The second exercise shows that merchanting's impact on the country's current account is sensitive to firm mobility.
\end{abstract}

Keywords: Merchanting, industry dynamics, current account adjustment

JEL Classification Number: F10, F20, F32

\footnotetext{
*The authors would like to thank participants of the Swiss National Bank's Brown Bag Workshop for helpful comments, and Laurence Wicht for data assistance. The views expressed in this paper are solely the responsibility of the authors and should not be interpreted as reflecting the views of the Swiss National Bank.

†Corresponding author information: email: andreas.fischer@snb.ch, telephone: +41 446313294 , FAX: +41446313980
} 


\section{Introduction}

Merchanting can be considered as an offshore business. A merchanting firm purchases goods from a supplier abroad and sells these on to a buyer abroad without the goods entering or leaving the firm's country of residence. These goods do not undergo any transformation between purchase and resale, and remain in the ownership of the firm. Thus a merchanting firm acts as an intermediary between companies that produce a good and companies that demand the good, both located abroad, by providing storage and transportation. Because merchanting is common in commodity trading, merchanting and commodity trading are often used as synonyms. However, in practice, merchanting involves trading of many other types of goods as well. The difference between revenues from the sale of such goods abroad and the incurred expenses to acquire, store, and transport them is recorded as (net) merchanting.

Merchanting has recently become a significant economic activity in some countries. Figure 1 plots merchanting as a share of GDP since 1990 for the four currently-largest merchanting countries, namely Finland, Ireland, Sweden, and Switzerland. The figure shows that merchanting grew steadily after 2000 and continued to expand even during the financial crisis. The dynamics for Ireland are particularly striking: merchanting as a share of GDP grew rapidly from $1.7 \%$ in 2004 to $4.7 \%$ in 2010.

The growing importance of merchanting as an economic activity has also had an impact on the level, persistence, and composition of the current account. Because the traded goods never enter or leave the firm's country of residence, the receipts and expenses of this activity are not recorded under trade in goods. Instead, merchanting is recorded under trade in services component. For some countries, merchanting's growth has generated large shifts in its trade balance, and contributed to a sizable current account surplus. ${ }^{1}$ Figure 1 also shows that merchanting displayed a large degree of per-

\footnotetext{
${ }^{1}$ In terms of Figure 1, Sweden's and Switzerland's current account with respect to GDP were $7.1 \%$ and $11.7 \%$ in 2011 . For the other countries, the same numbers are Finland $-0.7 \%$ and Ireland $0.1 \%$.
} 
sistence over time, and resisted the financial crisis well: A significant fall is not observed for merchanting. Current account balances that are driven by merchanting are thus also more persistent in their levels over time. ${ }^{2}$

This paper's objective is to show empirically that merchanting is an important driver of the current account and that firm dynamics can bring about rapid current account adjustment. Because merchanting firms reinvest their earnings abroad to expand their international activities, this practice raises national savings in the home country without increasing domestic investment. This results in a significantly large current account surplus. To show the empirical links between merchanting and the current account, two exercises are performed in this paper. The first exercise estimates the savings impact of merchanting countries in empirical models of the medium-term current account and shows that merchanting indeed increases the current account. The second exercise shows that merchanting's impact on the country's current account is sensitive to firm mobility.

These new empirical results for merchanting contribute to the international literature on external adjustment in two ways. A first contribution is to expand the list of determinants that explain medium-term current account behavior. The empirical model used in this study is closely related to empirical models in Chinn and Prasad (2003), Gruber and Kamin (2007, 2009), Chinn and Ito (2006, 2007, 2008), Lee et al. (2008), and Gagnon (2011). Using pooled regressions with cluster-corrected standard errors in a sample of 53 countries during 1980-2011, we show that merchanting increases the medium-term current account balance-to-GDP ratio on average by 3 percentage points. A second contribution is to show that the relocation of merchanting firms to other countries has large effects on a country's current account balance. The empirical results on firm mobility add to the growing literature on the interconnection between the fragmentation of firm activities in a globalized world and international macroeconomics. ${ }^{3}$

\footnotetext{
${ }^{2}$ The persistence of the current account driven by merchanting activity brings new challenges for global imbalances and external adjustment.

${ }^{3}$ This field is rapidly growing. Recent studies by Bems and Johnson (2012), Johnson and Noguera
} 
The paper is organized as follows. Section 2 defines merchanting. The same section provides statistical evidence that shows merchanting's high level of persistence even during the financial crisis. Section 3 describes the empirical methodology and the data used in the panel regression models. Sections 4 presents the empirical results. Section 5 concludes.

\section{Merchant trade: definitions and data}

This section discusses definitional issues in its first subsection. The second subsection illustrates the fact that merchanting activity is diverse across countries and sectors on the basis of select merchanting countries in our sample. In a third subsection summary statistics are presented to motivate the empirical analysis in section 4 .

\subsection{Definitions}

The IMF defines merchanting as the purchase of goods by a resident of the compiling economy from a nonresident combined with the subsequent resale of the same goods to another nonresident without the goods being present in the compiling economy, see the IMF Balance of Payments Manual, fifth edition (1993, pg.68). ${ }^{4}$ The amount recorded under merchanting is the amount received by the domestic resident from the foreign customer less the amount paid by the domestic resident to the foreign goods provider. The net profit resulting from these two transactions is recorded as a positive export value of business services, while any net loss is recorded as a negative export value of business services. Hereafter, we refer to net merchanting simply as merchanting.

(2012), and Johnson (2012), for example, highlight the importance of capturing the microstructure of trade relationships to better replicate international business cycles. See also section 2.1 on further information regarding fragmentation of firm activities.

${ }^{4}$ In this paper, the analysis for merchanting uses the IMF BPM5 classification, which treats merchanting as a component of trade in services. See IMF (2008) for a discussion how changes in the Balance of Payments Manual from BPM5 to BPM6 will influence how merchanting is to be reported in national statistics. 
Merchanting can arise from different sources and for any homogeneous tradeable good. ${ }^{5}$ A traditional form of merchanting is commodity broking where the merchanting firm buys and sells the goods from third parties and trades at world prices. A different case is where merchanting is the result of the international fragmentation of production processes within a firm and reflects the organizational plans of a global multinational that locates merchanting services in one country while the underlying production and ultimate distribution is elsewhere. In this case, the income from merchanting ultimately accrues to the foreign multinational and transfer pricing strategies might generate a measured current account surplus. ${ }^{6}$

\subsection{Characteristics of merchanting firms}

Merchanting's growth benefited strongly from the expansion of the global supply chain. The fragmentation and relocation of production processes have played a crucial part in merchanting's development. Although we are unaware of any empirical study that examines the microstructural features of merchanting firms, several observations can be offered.

A first feature is firm mobility. Merchanting firms are actively targeted by several countries. Singapore, for example, created the Global Trading Programme in 2001. The intention is to attract mobile commodity trading houses with low taxes and light regulation. ${ }^{7}$ Malaysia has a similar relocation program designed to attract 20 commodity trading firms by 2017. Firm relocation also explains why merchanting activities are concentrated in select cities: Dublin, Geneva, Hong Kong, Houston, London, and

\footnotetext{
${ }^{5}$ Computer chips, books, hazelnuts, chemical raw materials, crude oil are some examples.

${ }^{6}$ The same may hold for commodity traders that have vertically integrated production and distribution. The locational choice for merchanting services is often driven by tax optimization strategies. See Swiss National Bank (2012) for more information on merchanting.

${ }^{7}$ See for example the information under http://www.rikvin.com/taxation/singapore-corporate-tax-rates/ (retrieved on 20 March 2013) as well as "Singapore's low taxes lure Trafigura," Financial Times, 22.5.2012.
} 
Singapore. ${ }^{8}$ This agglomeration can partially be explained by the tax environment of the merchanting countries. The average corporate tax rate is lower in countries where merchanting is prevalent compared to countries where merchanting is absent. ${ }^{9}$.

A further feature of merchanting firms is the importance of international communication networks between buyers and sellers. This point is illustrated by Swiss merchanting. A large share of Swiss merchanting activity is in commodities. The possibility that a seafaring activity is conducted in a landlocked country stems from the fact that factors beyond transport costs matter: well established communication networks, the proximity of financial services, a non restrictive regulatory environment, and a flexible labor market.

Another feature of merchanting is that it is not concentrated in a specific sector across the globe. For example, in Switzerland, merchanting is concentrated in commodities, chemicals, and pharmaceuticals. In Finland, electronics and computers are the main merchanting activities, whereas in Ireland, publishing and chemical processing are important. ${ }^{10}$ This heterogeneity across sectors makes it difficult to create a merchanting index that captures their activities across time. ${ }^{11}$

\subsection{Properties of the data}

The number of economies reporting merchanting has increased in recent years. Nevertheless, only 67 economies reported merchanting data to the IMF for $2010{ }^{12}$ Some of the largest economies (including China, the United Kingdom, and the United States)

\footnotetext{
${ }^{8}$ Furthermore, merchanting is often highly concentrated among large firms. In the Irish case, the top ten companies account for approximately $70 \%$ to $80 \%$ of overall merchant trade in 2010 (Private correspondence with the Irish Central Bank.) Similar to Ireland, the eight largest merchanting firms are responsible for 70\% of Switzerland's merchanting activity (see Beusch and Döbeli (2012)).

${ }^{9}$ See Table A2 in the Appendix

${ }^{10}$ This information is based on email exchanges with national authorities.

${ }^{11}$ The problem is further compounded by the fact that often national statistical agencies do not record merchanting's export destination or the activity's sector.

${ }^{12}$ Close to 200 countries reported balance of payments data to the IMF for that year. Among the 67 countries with merchanting data in 2010, 15 entries were identically zero.
} 
and some likely important merchanting economies (including Hong Kong and Singapore) did not report merchanting data to the IMF. ${ }^{13}$

Following the existing literature on the determinants of the medium-term current account, such as Lee et al. (2008), we choose our sample consisting of 53 countries which would cover about $90 \%$ of the world GDP. The countries in our sample are listed in the Appendix. Within our sample, merchanting data is available only for 27 countries from the IMF BOPS in 2007. ${ }^{14}$ Therefore we extend and expand the available data on merchanting by using data provided by central banks and/or national statistical offices. Thus our dataset has merchanting data for 35 countries in 2010. Still merchanting data on some important countries are missing in our sample. ${ }^{15}$

Figure 2 plots the merchanting-to-GDP ratio on the horizontal axis and the current account-to-GDP ratio in 2010 for these 35 countries with available merchanting data. The figure shows that merchanting is relatively small for most countries. However, in most countries with a sizeable level of merchanting activity, i.e., greater than $0.5 \%$ of GDP, merchanting seems to contribute to a sizeable current account surplus. We observe that the positive merchanting positions are large and concentrated among many small open economies with current account surpluses. By contrast, the negative merchanting positions tend to be small and are dispersed across many countries without a clear relationship with the current account. Based on these observations from Figure 2, our empirical analysis focuses on countries with a positive value in merchanting.

${ }^{13}$ Some countries provided data in the past but no longer do. Sweden and the Netherlands are a case in point. The problem of missing observations for the non reporting countries is compounded by an underreporting bias for those countries that do report. First, there is the problem of lagged reporting when new firms are identified to be engaged in merchanting activities. Second, not all merchanting firms are identified in the country BOP surveys. We do not attempt to correct for these problems, but note that these biases understate results presented in section 4 .

${ }^{14}$ However, merchanting is identically zero for two countries.

${ }^{15}$ Hong Kong's Census and Statistics Department publishes data on the "gross margin involved in merchanting" as part of Hong Kong's offshore trade statistics. We however chose to not include this data because the high value (approx. 11\% of GDP in 2011) and Hong Kong's trade links with China suggest that merchanting in Hong Kong is not comparable with merchanting as we understand it based on the Balance of Payments Manual. 
Table 1 provides statistical information for the 13 countries that we call merchanting countries in the empirical section 4. These countries have had a merchanting-to-GDP ratio of $0.5 \%$ or higher for at least one year during our sample period 1980-2011. All measures in Table 1 are expressed as a share of GDP. The country rank for merchanting, shown in the first column, is based on the average merchanting value during 2008-2011. Next, the table presents mean, standard deviation, minimum, and maximum values for merchanting based on annual data from 2000 to 2011. Four countries have an average merchanting income greater than 1\% of GDP. These are Finland, Ireland, Sweden, Switzerland. The standard deviations are small and do not show large discrepancies. The minimum values show that apart from Malaysia, all the merchanting countries register positive merchanting during 2000 and $2011 .^{16}$

The last four columns of Table 1 show data on merchanting/GDP, goods balance/GDP, services (excluding merchanting)/GDP, and the current account/GDP for these countries. All figures are net balances for the year 2011. For Belgium and Finland, merchanting is larger than the goods and the service balance (excluding merchanting). The last column shows that almost all merchanting countries have positive current account/GDP ratios.

To motivate the empirical analysis in section 4, Figure 3 offers a descriptive observation as to whether merchanting mitigates adjustments in the trade balance in the merchanting countries. ${ }^{17}$ It is generally believed that the trade imbalance can be corrected through external demand or exchange rate adjustments. To determine whether merchanting behaves similarly to other trade components, Figure 3 plots merchanting, trade in goods, and trade in services (excluding merchanting) for the last decade. Each series is expressed

${ }^{16}$ The IMF Balance of Payments Statistics includes values for Ireland for the years 2000 and 2001 ($1.1 \%$ and 0) too. Based on the information that the Central Statistics Office of Ireland only started to collect data on merchanting in 2004 we ignore these earlier values. It should also be noted that the Belgian time series includes breaks due to methodological changes from 2006 to 2007, and 2009 to 2010.

${ }^{17}$ The three observations for Luxembourg are not displayed but follow similar patterns as described further in the text. 
in terms of net balances and as a ratio of GDP. For each country, merchanting is less volatile than the other two series. A striking feature of the three time series is that merchanting was hardly affected by the financial crisis (post 2007) or by the great trade collapse (2008-2009), whereas the other two series reveal temporary or even structural shifts. Figure 3 also offers additional information to the information offered in Table 1. It shows that merchanting has been increasing or stable over time for all countries for which merchanting is substantial according to our definition. Furthermore, it also shows a slow compositional shift from trade in goods towards merchanting in countries like Switzerland and Sweden.

The analysis on positive merchanting positions is also motivated by the linkages between export volatility and external savings. ${ }^{18}$ For example, it is argued that volatile oil exports lead to an increase in precautionary savings, which results in a positive external balance. ${ }^{19}$ By contrast, a visual inspection of Figure 3 suggests that merchanting firms' revenues exhibit a high level of persistence on the aggregate country level. While a smooth revenue stream may lower the need for precautionary savings, merchanting firms invest their earnings abroad to expand their activities. This structural feature of merchanting firms increases the savings-investment gap and thereby increases the current account surplus. ${ }^{20}$

A simple regression analysis supports the view that while the share of merchanting

${ }^{18}$ There is a large literature that examines the links between export income volatility and external savings. Recent examples include Cherif and Hasanov (2012) and Bems and de Carvalho Filho (2011).

${ }^{19}$ As a consequence, volatile export revenues of oil producing countries are often filtered out of empirical models of the medium-term current account. See in particular Lee et al. (2008), Chinn and Prasad (2003), Gruber and Kamin $(2007,2009)$, Chinn and Ito (2006, 2007, 2008), and Gagnon (2011).

${ }^{20} \mathrm{~A}$ further consideration for external adjustment, not pursued in this paper, is a firm's sensitivity to exchange rate movements. Bosworth and Collins (2010), Crane et al. (2007), and Wren-Lewis and Driver (1998) highlight the observation that external adjustment through trade in services is slower than through trade in goods. The common view is that an exchange rate appreciation facilitates external adjustment to correct a trade surplus. Because a large share of merchanting activity brings together buyers and sellers of standardized products (i.e., commodities, microchips, etc) traded outside of the national borders, the volume of this service is heavily dependent on global demand and less on domestic currency movements. This means that merchanting should be less sensitive to exchange rate movements than say trade in goods. 
is growing in some countries, it is also highly persistent. Table 2 presents panel $\mathrm{AR}(1)$ regressions for those 38 countries for which we have merchanting data. The coefficient for the lagged variable is considerably higher for merchanting (i.e., 0.82) than for trade in goods (0.72) and trade in services excluding merchanting (0.79). It is also important to note that the crises dummies for the years 2008 and 2009 are not significant for merchanting. This says that merchanting was not heavily influenced by the financial crisis. This is not true for the other trade components.

To highlight the smoothness of merchanting over the financial crisis, variances of the residuals from the $\mathrm{AR}(1)$ regression in Table 2 are presented in Table 3. In all periods considered, the variance of the residuals for merchanting is negligible compared to that of trade in services and that of trade in goods. In particular, during the post-crisis period the variance of the residuals for trade in services and trade in goods increased, while that of merchanting does not show a different behavior compared to the pre-crisis period.

The properties of increasing size and high persistence mean that merchanting does not behave like other components in the trade balance. These properties also imply that the current account balance of merchanting countries becomes more sticky. In other words, larger adjustments in either the exchange rate or external demand are needed to correct imbalances in the merchanting countries. These issues are analyzed more formally in the next sections.

\section{Empirical methodology}

The empirical framework used to estimate the medium-term determinants, i.e., four-year averages, on current account balances follows Lee et al. (2008). In this model, the pooled 
regression is specified as follows:

$$
C A_{i t}=\alpha+\beta X_{i t}+\gamma D_{i t}+\epsilon_{i t}
$$

where $C A_{i t}$ is the current account balance of country $i$ expressed as a share of GDP for year $t$. Similarly, $X_{i t}$ is a vector of macroeconomic and demographic variables, $D_{i t}$ captures institutional or structural features through dummy variables, and $\epsilon_{i t}$ denotes the residual. In our setup, equation (1) is extended to include merchanting:

$$
C A_{i t}=\alpha+\beta X_{i t}+\gamma D_{i t}+\rho M_{i t}+\epsilon_{i t}
$$

where $M_{i t}$ captures the merchanting activities of country $i$. Merchanting, $M_{i t}$ is a dummy: +1 if merchanting with respect to GDP $>0.5 \%$ in a particular year; otherwise 0 . A threshold of $0.5 \%$ is used to capture merchanting effects of a certain volume. The impact effect is expected to be positive. The sample of 13 merchanting countries is given in Table 1.

The sample follows Lee et al. (2008) and covers 53 countries for the period 1980-2011. ${ }^{21}$ The panel is unbalanced, meaning that for some variables the length of the series varies by country due to missing data. The Appendix lists the data sources and offers brief comments.

The macroeconomic and demographic variables, $X_{i t}$, in equation (2) are standard in the literature and are briefly discussed next. ${ }^{22}$ These variables include the fiscal balance, demographic determinants, net foreign assets (NFA), and economic growth. For the fiscal balance, it is assumed that a higher government budget balance raises national saving. This, in turn, increases the current account balance. ${ }^{23}$ The fiscal balance in equation (2)

\footnotetext{
${ }^{21}$ See Appendix for a list of the countries.

${ }^{22}$ See also Appendix 2.1 in Lee et al. (2008) for further discussion of the database.

23 Only in the case of Ricardian equivalence, where private saving fully offsets changes in public saving, is the link broken between government budget balances and current account balances.
} 
is defined as the ratio of the general government budget balance to GDP in deviation from the average budget balance of trading partners: if the government budget balance improves in all countries, there would be a world-wide macroeconomic effect but little expected effect on the current account balance of each country.

The demographic determinants assume that a higher share of the economically inactive dependent population reduces national saving and decreases the current account balance. To proxy for this, Lee et al. (2008) include an old-age dependency ratio as well as population growth. The intention of the latter variable is to capture the share of economically dependent young people. Both demographic variables are measured in deviation from trading-partner averages and are expected to decrease the current account balance.

NFA enters as a determinant in equation (2). The assumption is that economies with a high NFA benefit from higher net foreign income flows, which tend to create a positive association between NFA and current account balances. The initial NFA position is used in equation (2) to avoid capturing a reverse link from the current account balance to NFA.

Economic growth is included for two reasons. If economies in the early stages of development have a greater need for investment, this is often financed through external borrowing. As developing economies grow and approach the income levels of advanced economies, their current account balances should improve. Alternatively, if countries are at a similar stage of development, the stronger economic growth relative to its trading partners should lower the current account balance.

Equation (2) includes two measures of growth. The first variable is the ratio of GDP per capita in purchasing power parity terms to the U.S. level, which Lee et al. (2008) define as relative income. This variable is assumed to measure the relative stage of economic development. The second growth variable is the deviation of the real per 
capita GDP growth rate from its trading partner average. This variable is used to capture relative economic growth. In equation (2), the current account balance is expected to increase with relative income but to decrease with relative growth.

Equation (2) also includes countries' oil balance. Higher oil prices increase the current account balance of oil-exporting countries and decrease the balance of oil-importing countries. In equation (2), Norway is treated as a separate oil country because of its high level of intergenerational savings.

Several dummy variables, $D_{i t}$, are included in equation (2) to capture country or industry specific features. ${ }^{24}$ A dummy that controls for small open economies with large financial centers is included among others. The evidence in Lee et al. (2008) shows that financial centers tend to run substantial current account surpluses. This effect is captured with a dummy for the following countries: Belgium, Hong Kong, Luxembourg, the Netherlands, Singapore, and Switzerland.

Empirical evidence shows that crisis dummies have an impact even after controlling for a range of macroeconomic factors. Chinn and Ito (2006), Gagnon (2011), and Lee et al. (2008) show that economic crises tend to unleash strong current account adjustments as a by-product of macroeconomic contraction because of the reduced availability of international financing. Two sets of crises dummies are considered. The first dummy controls for the Asian crisis. Aizenman (2008) and others argue that Asian countries increased their precautionary savings after the Asian crisis to insure themselves against future crisis. This dummy acts as a levels shift. The second dummy captures episodes of banking crises. We use the Laeven and Valencia (2010) measure of international banking crises. The motivation is to capture temporary output losses that are linked to banking crises.

A last set of dummy variables control for aging societies and the introduction of the euro. These dummies have not been used extensively in the literature but do enter

\footnotetext{
${ }^{24}$ In the four year-averages the dummy is set to +1 if it takes value +1 in one of the four years.
} 
the Lee et al. (2008) setup. The aging dummy is +1 for Germany, Italy, Japan, and Switzerland and 0 for the rest. This dummy treats the four aging societies as outliers. Further, we introduce a first euro dummy that takes value +1 for Germany starting in 1999 and 0 for all other countries, and a second euro dummy that takes value +1 for Greece, Portugal, and Spain, and 0 for all other countries. The intention here is to capture potential extreme countries within the currency union. In the specification where we replicate Lee et al. (2008) there is only one euro dummy with value +1 for Germany, -1 for Greece, Portugal, and Spain, and 0 for the rest.

\section{The empirical impact of merchanting in medium-term CA models}

This section presents the empirical results. The first set of results presented in subsection 4.1 show that merchanting is a robust determinant of the current account. Merchanting's impact effect of $3 \%$ in the baseline specification is sizable. Further robustness checks are presented in subsection 4.2. The regressions show that the results from 4.1 are not sensitive to different specifications of the merchanting dummy. The last set of results in subsection 4.3 consider the importance of firm relocation. The empirical findings show that the relocation of merchanting firms to a single economy does not weaken the empirical effect found for the baseline estimates.

\subsection{Merchanting countries in medium-term current account models}

Our baseline regressions of equation (2) are presented in Table 4. Column 1 shows regression estimates for the medium-term model as specified by Lee et al. (2008) without dummy variables. All the estimated coefficients are correctly signed, however the demographic and growth variables are statistically insignificant. Column 2 shows the same 
regression but now adds the merchanting dummy. This variable has a coefficient of 0.04 and is statistically significant at the $1 \%$ level. This result says that the current account is increased by $4 \%$ for those countries that have merchanting income greater than $0.5 \%$ of GDP. In other words, merchanting increases the current account balance.

Next, the Asian crisis dummy is added to the specification. The regressions with and without the merchanting dummy are shown in columns 3 and 4 . The regression estimates in column 4 show that merchanting unleashes almost the same level of external savings as the Asian crisis. Both dummies are highly statistically significant.

A further check is to determine whether merchanting holds up with other dummies that have been argued to be important. The regressions in columns 5 and 6 include the small financial centers dummy, the banking crisis dummy, the euro dummy, and the aging dummy. The regression in column 6 shows that the strength of these dummy variables is weakened once merchanting is introduced. For example, the dummy for small financial centers is no longer significant in column 6. The significance of the euro dummy is only significant at $10 \%$ level when merchanting is introduced. Similarly, the banking and the aging dummies never figure prominently with or without merchanting.

Another check is to compare the results in Table 4 with the estimates from Lee et al. (2008). For this exercise, we shorten our sample from 1980 to 2007 and consider the alternative specification in Lee et al. (2008) based on the lagged current account. ${ }^{25}$ These results are given in Table 5 . Columns 2 and 5 show that the merchanting dummy remains significant in the shortened samples for the NFA and the lagged capital account specification. Our estimates for the NFA specification in column 1 are close to the estimates of Lee et al. (2008) shown in column 3 under the IMF heading. The main difference in the coefficients is for population growth. In Lee et al. (2008), this coefficient is about six times smaller. Instead for the lagged current account specification shown in

${ }^{25}$ The Lee et al. (2008) sample is from 1973 to 2004 . Hence, we are unable to fully replicate their results. 
columns 4 to 6 , there is the additional difference for the coefficient on the fiscal balance. Our estimates show that this coefficient is five times smaller and statistically insignificant compared to the estimates by Lee et al. (2008), which are reproduced in column 6 .

\subsection{Merchanting countries: robustness checks}

In this subsection, alternative definitions of merchanting countries are shown to be robust in equation (2). The previous regressions were based on a single definition for merchanting countries, i.e., whether merchanting in a year is greater than $0.5 \%$ with respect to GDP. The regression results with alternative definitions of merchanting countries are presented in Table 6.

The regressions show that the volume of merchanting activity is important for its impact on the current account. The regressions in the first three columns define a dummy variable to equal one if a country reports positive or negative merchanting values at least once during the averaged 4 years. In each of these regressions, merchanting is not statistically significant. The regression in column 4 uses the definition from Table 4 with a threshold of $0.5 \%$. It is reproduced for completeness. Next, in the regression shown in column 5, the threshold is increased from $0.5 \%$ to $1.0 \%$. Here, there is no

difference in the estimates between the regressions in columns 4 and 5. Similarly, the regression in column 6 augments the threshold to $2.0 \%$ with no change in the coefficient and in statistical significance. These results show that the definition used in Tables 4 and 5 is robust to higher threshold levels.

\subsection{The relocation of merchanting firms}

Merchanting is subject to firm relocation. In section 2.2, it was noted that several Asian countries seek to attract merchanting firms. In this section, we consider whether our previous estimates are robust to firm relocation and whether small and large countries are equally affected. The exercise assumes that global merchanting activity relocates 
either to Singapore, a small country, or the United States, a large country, in 2004. For this purpose, we subtract the nominal values of merchanting from all countries' current account starting from 2004 onwards, as well as from their GDP. We add these values to the data of either Singapore or the US. Next, we calculate new merchanting/GDP ratios for all countries for 2004-2007 and 2008-2011. All other variables that enter the regression normalized by GDP are also adjusted accordingly. With these hypothetical data, we run the same regression as in section 4.1, and consider the impact of merchanting on the current account.

The relocation results show that merchanting affects the current account of both countries. More importantly, firm relocation to Singapore can increase the country's already large current account surplus. Alternatively, in the U.S. case, it can improve the country's trade balance and contribute to the narrowing of global imbalances.

Table 7 presents the regression results of firm relocation. The regressions show that if merchanting were to be concentrated in a single country starting from 2004 onwards, merchanting would still affect the current account of both countries. We begin with the baseline regressions of no relocation shown in columns 1 and 2. They are reproduced from Table 4. Again, they show that merchanting activity beyond a certain volume raises external savings by $3 \%$ on average. Next, the regressions in columns 3 and 4 show the impact of global merchanting relocating to the United States. The results show that the U.S. current account would improve by $2 \%$ if relocation occurred but the impact is statistically insignificant. Similarly, the regressions in columns 5 and 6 perform the same exercise for Singapore. The panel estimates in column 6 show that average external savings would increase by $7 \% .^{26}$

\footnotetext{
${ }^{26}$ The choice of the relation date 2004 was at a critical juncture of global merchanting. If the relocation date is set in 2008 instead of 2004, the impact is in the order of $5 \%$ and $3 \%$ respectively and significant for both countries.
} 


\section{Conclusion}

Merchanting has become an important component in the current account for several countries. This activity grew steadily in the last decade because of the fragmentation of production processes. Merchanting proved to be crisis resistent, thus increasing a country's current account balance even at a time when global imbalances were temporarily shrinking. Panel regressions show that merchanting increases a country's current account by $3 \%$ with respect to GDP, about the size of precautionary savings stemming from the Asian crisis. Because many countries do not report merchanting activities, the estimated impact of merchanting on the current account balance is certainly larger.

The size and persistence of merchanting has changed the dynamics of a country's current account. Merchanting mitigates external adjustment in that it raises national savings without increasing domestic investment. The importance of merchanting in the medium-term current account models also has implications for the adjustment debate on global imbalances. Because merchanting is difficult to predict (i.e., poor data quality and firm relocation), this introduces a further source of uncertainty in studies by Cline and Williamson (2011), Lee et al. (2008), and others that make exchange rate assessments based on medium-term current account models.

The empirical evidence for merchanting supports several directions for future research. One avenue would be to develop a theoretical model that shows why merchanting improves the current account balance. A starting point would be to assume that large merchanting activity reflects temporary monopoly power in an intertemporal smoothing model. Another avenue that merits greater analysis is estimating merchanting's sensitivity to exchange rate movements. Our conjecture is that merchanting is less sensitive to real exchange rate movements, than say, is trade in goods. While several studies highlight the differences in exchange rate elasticities between goods and services, elasticities for merchanting across sectors have not been estimated. 


\section{References}

Aizenman, J., 2008. Large hoarding of international reserves and the emerging global economic architecture. The Manchester School 76, 487-503.

Bems, R., de Carvalho Filho, I., 2011. The current account and precautionary savings for exporters of exhaustible resources. Journal of International Economics 84, 48-64.

Bems, R., Johnson, R.C., 2012. Value-added exchange rates: measuring competitiveness with vertical specialization in trade. Mimeo.

Beusch, E., Döbeli, B., 2012. SNB Policy Brief 2012-10: The most important merchanting companies in the Swiss CA. Mimeo.

Bosworth, B., Collins, S., 2010. Rebalancing the US economy in a postcrisis world. ADBI Working Paper 236. Asian Development Bank Institute.

Cherif, R., Hasanov, F., 2012. Oil Exporters' Dilemma: How Much to Save and how Much to Invest. IMF Working Paper 12/4. International Monetary Fund.

Chinn, M.D., Ito, H., 2006. What matters for financial development? capital controls, institutions, and interactions. Journal of Development Economics 81, 163-192.

Chinn, M.D., Ito, H., 2007. Current account balances, financial development and institutions: Assaying the world "saving glut". Journal of International Money and Finance 26, 546-569.

Chinn, M.D., Ito, H., 2008. Global current account imbalances: American fiscal policy versus East Asian savings. Review of International Economics 16, 479-498.

Chinn, M.D., Prasad, E.S., 2003. Medium-term determinants of current accounts in industrial and developing countries: an empirical exploration. Journal of International Economics 59, 47-76. 
Cline, W.R., Williamson, J.H., 2011. Estimates of Fundamental Equilibrium Exchange Rates, May 2011. Policy Briefs 11-5. Peterson Institute for International Economics.

Crane, L., Crowley, M., Quayyum, S., 2007. Understanding the evolution of trade deficits: Trade elasticities of industrialized countries. Economic Perspectives 31, 2 17.

Gagnon, J.E., 2011. Current account imbalances coming back. Workingpaper 11-1. Peterson Institute for International Economics.

Gruber, J., Kamin, S., 2009. Do differences in financial development explain the global pattern of current account imbalances? Review of International Economics 17, 667688.

Gruber, J.W., Kamin, S.B., 2007. Explaining the global pattern of current account imbalances. Journal of International Money and Finance 26, 500-522.

IMF, 1993. Balance of Payments Manual. Fifth ed., International Monetary Fund, Washington, D.C.

IMF, 2008. Impact on BOP data of changes in international standards for processing and merchanting. Twenty-First Meeting of the IMF Committee on Balance of Payments Statistics (BOPCOM-08/11). International Monetary Fund. Washington, D.C.

Johnson, R.C., 2012. Trade in Intermediate Inputs and Business Cycle Comovement. NBER Working Papers 18240. National Bureau of Economic Research.

Johnson, R.C., Noguera, G., 2012. Fragmentation and Trade in Value Added over Four Decades. NBER Working Papers 18186. National Bureau of Economic Research.

Laeven, L., Valencia, F., 2010. Resolution of Banking Crises: The Good, the Bad, and the Ugly. IMF Working Papers 10/146. International Monetary Fund. 
Lee, J., Milesi-Ferretti, G.M., Ostry, J., Prati, A., Ricci, L.A., 2008. Exchange rate assessments: CGER methodologies. Occasional Paper 261. International Monetary Fund.

Swiss National Bank, 2012. Merchanting in Switzerland. Swiss Balance of Payments 2011 .

Wren-Lewis, S., Driver, R., 1998. Real exchange rates for the year 2000. volume 54. Peterson Institute for International Economics. 


\section{Appendix}

\section{Data description}

Sample:

Algeria, Argentina, Australia, Austria, Belgium, Brazil, Canada*, Chile*, China*, Columbia, Croatia*, Czech Republic, Denmark, Egypt*, Finland, France, Germany, Greece, Hong Kong*, Hungary, Indonesia*, India, Ireland, Israel*, Italy, Japan, Korea, Luxembourg, Malaysia, Mexico, Morocco, New Zealand, Netherlands, Norway*, Pakistan, Peru*, Philippines, Poland, Portugal, Russia, Singapore*, Slovakia, Slovenia, South Africa*, Sweden, Switzerland, Spain, Thailand*, Tunisia, Turkey, Venezuela*, United Kingdom, United States*.

Countries denoted with a $*$ have no available merchanting data during the sample period $1980-2011$.

Merchanting Dummy:

Austria (7), Belgium (3), Denmark (2), Finland (3), France (1), Germany (1), Hungary (2), Ireland (2), Luxembourg (1), Malaysia (1), Netherlands (1), Sweden (4), Switzerland (3).

Note: The number of observations where the dummy is +1 , i.e., when Merchanting/GDP $>0.5 \%$ is given in the parentheses. Numbers in bold denote a sequence of +1 dummy values that terminate with the final observation. For example, Denmark (2) denotes a dummy of +1 for the observation 2004-2007 and 2008-2011, otherwise the dummy is zero. 
Table A1: Data and their sources

\begin{tabular}{|c|c|c|c|}
\hline Variable & Source & Projection & Comment \\
\hline Current account & IMF BOPS & WEO & Measured as ratio to GDP \\
\hline GDP & WDI & WEO & Real GPD in 2000 USD. \\
\hline Fiscal balance & WEO & WEO & General government net lending $^{\dagger}$ \\
\hline $\begin{array}{l}\text { Old-age } \\
\text { dependency ratio }\end{array}$ & UN & UN & $\begin{array}{l}\text { Old-age dependency ratio (population } \\
\text { between } 30 \text { and } 64 \text { as ratio to population }> \\
65) .^{\dagger}\end{array}$ \\
\hline $\begin{array}{l}\text { Population } \\
\text { growth }\end{array}$ & $\mathrm{UN}$ & $\mathrm{UN}$ & Population growth ${ }^{\dagger}$ \\
\hline GDP growth & WDI & WEO & GDP growth (per capita, real LCU) ${ }^{\dagger}$ \\
\hline $\begin{array}{l}\text { Initial net } \\
\text { foreign assets } \\
\text { (NFA) }\end{array}$ & IFS, LM & IFS, LM & $\begin{array}{l}\text { When NFA is missing in the Lane and } \\
\text { Milesi-Feretti data, it is substituted with } \\
\text { IFS data. }\end{array}$ \\
\hline $\begin{array}{l}\text { Oil balance, } \\
\text { Norway }\end{array}$ & WDI & WEO & \\
\hline $\begin{array}{l}\text { Oil balance, } \\
\text { others }\end{array}$ & WDI & WEO & $\begin{array}{l}\text { Swiss oil balance is estimated for the } \\
\text { projection (not contained in WEO). }\end{array}$ \\
\hline Relative income & CGER & WEO & $\begin{array}{l}\text { Relative income (ratio of per capita PPP } \\
\text { GDP to US level, } 2000 \text { USD). }\end{array}$ \\
\hline Merchanting & BOPS, other & BOPS, other & $\begin{array}{l}\text { Missing BOPS data is replaced by central } \\
\text { bank and statistical offices' data whenever } \\
\text { possible. }\end{array}$ \\
\hline Trade data: & & & \\
\hline $\begin{array}{l}\text { Non-oil and oil } \\
\text { trade }\end{array}$ & DOTS, WDI & & $\begin{array}{l}\text { Total exports/imports from DOTS, fuel } \\
\text { exports/imports from WDI. }\end{array}$ \\
\hline $\begin{array}{l}\text { Goods and } \\
\text { services trade }\end{array}$ & UN & & \\
\hline $\begin{array}{l}\text { Weights for } \\
\text { global } \\
\text { consistency } \\
\text { calculation }\end{array}$ & DOTS & & Own calculation \\
\hline $\begin{array}{l}\text { Weights for } \\
\text { deviation from } \\
\text { trading partner }\end{array}$ & $\mathrm{UN}$ & & Own calculation \\
\hline \multicolumn{4}{|c|}{ Dummy variables: } \\
\hline Banking crisis & LV & & $\begin{array}{l}\text { Laeven and Valencia (2010) class. } \\
\text { Borderline crises are not taken into account. }\end{array}$ \\
\hline Asian crisis & Lee et al. (2008) & & $\begin{array}{l}\text { Asian crisis } 1997-20111=\text { emerging Asia } \\
\text { countries as classified by IMF; } 0=\text { all other. } \\
\text { See Lee et al. (2008). }\end{array}$ \\
\hline Financial center & Lee et al. (2008) & & $\begin{array}{l}1=\text { Switzerland, Luxembourg, Hong Kong, } \\
\text { Netherlands, Singapore, Belgium; } 0=\text { all } \\
\text { other. See Lee et al. (2008). }\end{array}$ \\
\hline $\begin{array}{l}\text { Euro } \\
\text { introduction }\end{array}$ & Lee et al. (2008) & & $\begin{array}{l}1=\text { Germany, }-1=\text { Portugal, Spain, Greece; } \\
0=\text { all other. }\end{array}$ \\
\hline — : Germany & own & & $1=$ Germany; $0=$ all other. \\
\hline — : Periphery & own & & $1=$ Portugal, Spain, Greece; $0=$ all other. \\
\hline $\begin{array}{l}\text { Aging } \\
\text { population }\end{array}$ & Lee et al. (2008) & & $\begin{array}{l}1=\text { Germany, Switzerland, Japan, Italy; } \\
0=\text { all other. }\end{array}$ \\
\hline
\end{tabular}

$\dagger$ Measured in deviation of trading partner average. 


\section{Tax rates in merchanting countries}

Average corporate tax rates have been lower in countries where merchanting has been prevalent compared to countries where merchanting has been absent. Between 2000 and 2010, the average corporate tax rate in the 12 merchanting countries in our sample was $25 \%$, whereas for the non merchanting countries it was $30 \%$. Table A2 below lists average and latest tax rates for merchanting versus no-merchanting countries. The (unweighted) average measure based on World Bank corporate tax rates understates the true difference between merchanting and non merchanting countries. Several countries, such as Hong Kong, Singapore, and the United States, which we define as non-merchanting country in the empirical analysis because of a lack of merchanting data, also have low corporate taxes. Further, for some countries, taxes for merchanting activity is considerably lower than the national corporate tax rates.

Table A2: Tax rates for merchanting countries

\begin{tabular}{|c|c|c|c|c|}
\hline & \multicolumn{2}{|c|}{ Average 2000-2010 } & \multicolumn{2}{|c|}{ Latest year ${ }^{\dagger}$} \\
\hline & merchanting & no merchanting & merchanting & no merchanting \\
\hline Profit tax ${ }^{a}$ & - & - & $13.81 \%$ & $16.89 \%$ \\
\hline Income, profit \& capital gains $\operatorname{tax}^{b}$ & $25 \%$ & $30.21 \%$ & $23.52 \%$ & $29.76 \%$ \\
\hline Total tax rate ${ }^{c}$ & $45.11 \%$ & $48.46 \%$ & $43.52 \%$ & $46.17 \%$ \\
\hline \multicolumn{5}{|c|}{$\begin{array}{l}\text { Data is from the World Bank. Merchanting countries are defined in the appendix. No } \\
\text { merchanting countries are } 44 \text { countries, i.e., the rest of the sample. } \\
\dagger 2010 \text { values for income and total tax rate. } 2011 \text { for profit tax } \\
{ }^{a} \text { Profit tax in \% of commercial profit. } \\
{ }^{b} \text { Taxes on income, profits and capital gains (measured as \% of revenue) are levied on the actual or } \\
\text { presumptive income of individuals, on the profits of corporations and enterprises, and on capital } \\
\text { gains, whether realized or not, on land, securities, and other assets. Intra-governmental payments } \\
\text { are eliminated in consolidation. }\end{array}$} \\
\hline
\end{tabular}


Figure 1: Merchanting/GDP

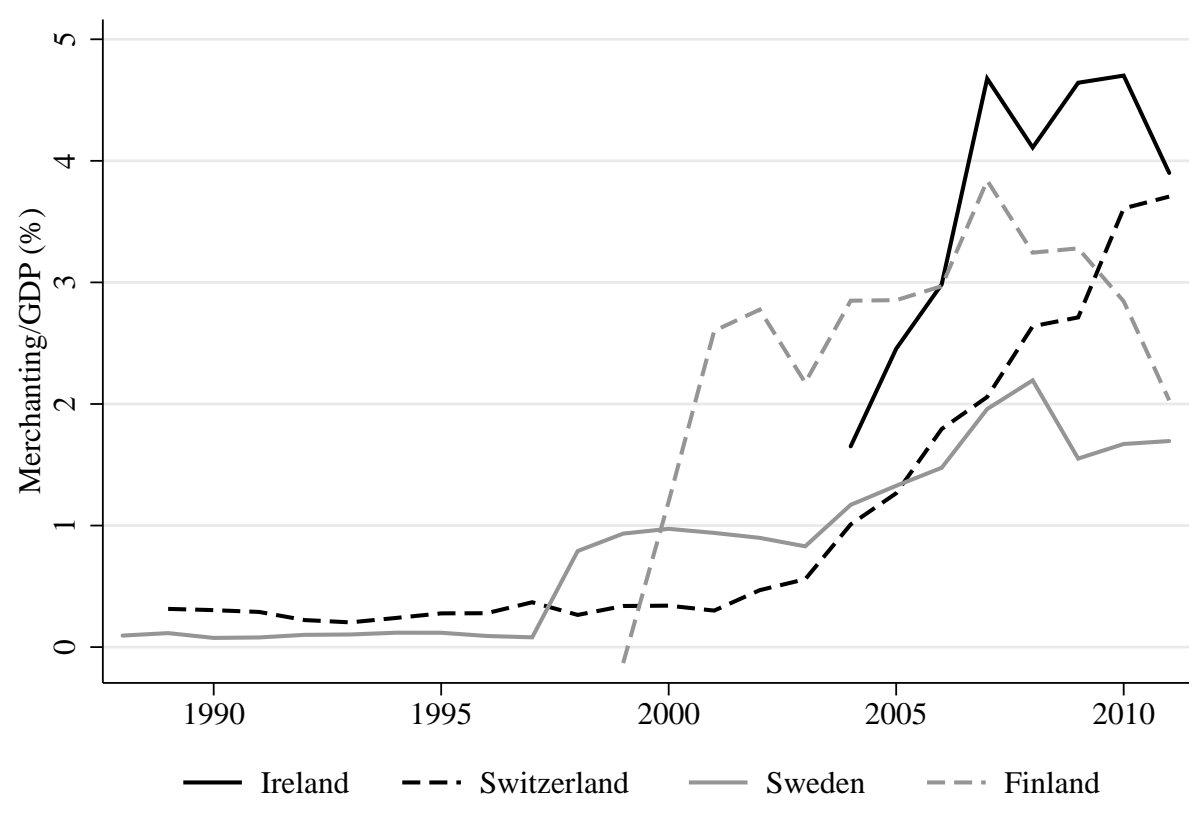

Source: IMF BOPS, national institutions, WDI

Figure 2: Merchanting/GDP and CA/GDP balances in 2010

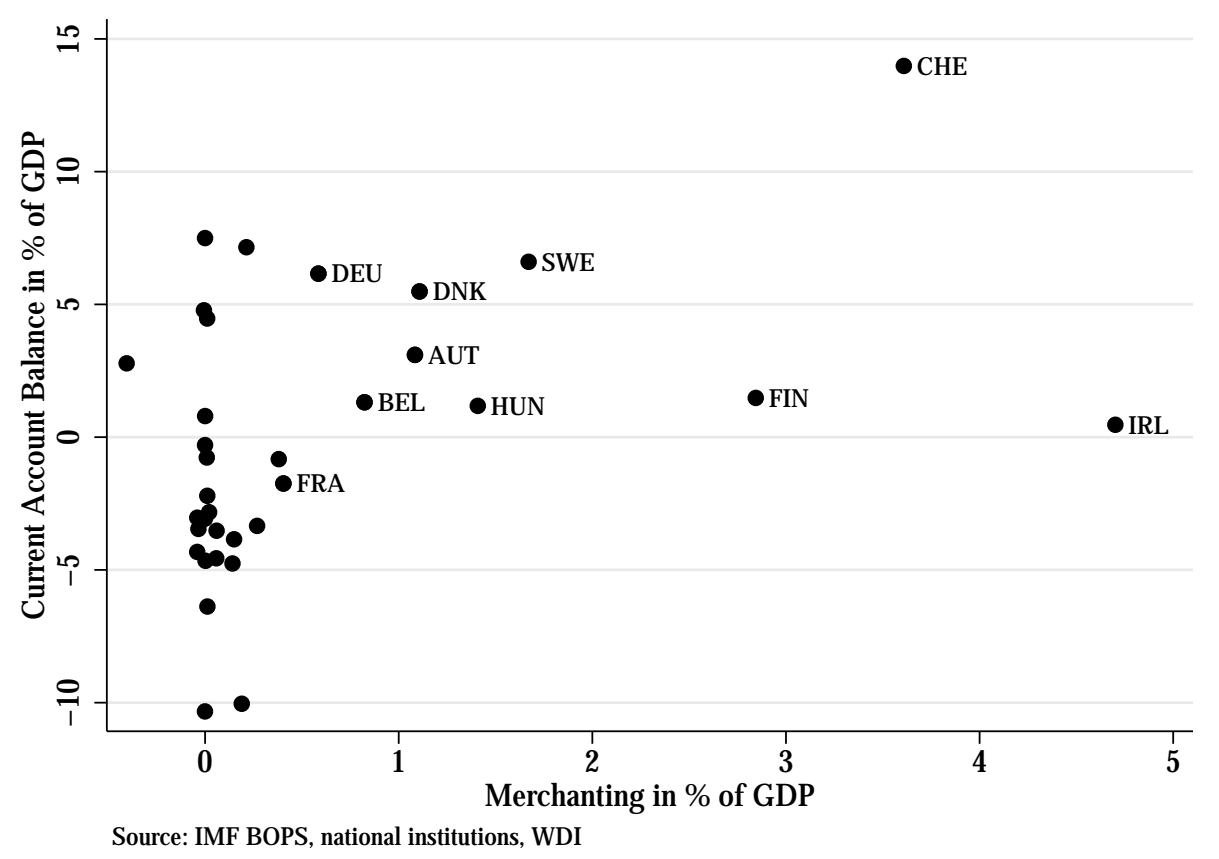


Figure 3: Components of the current account in merchanting countries (\% of GDP)
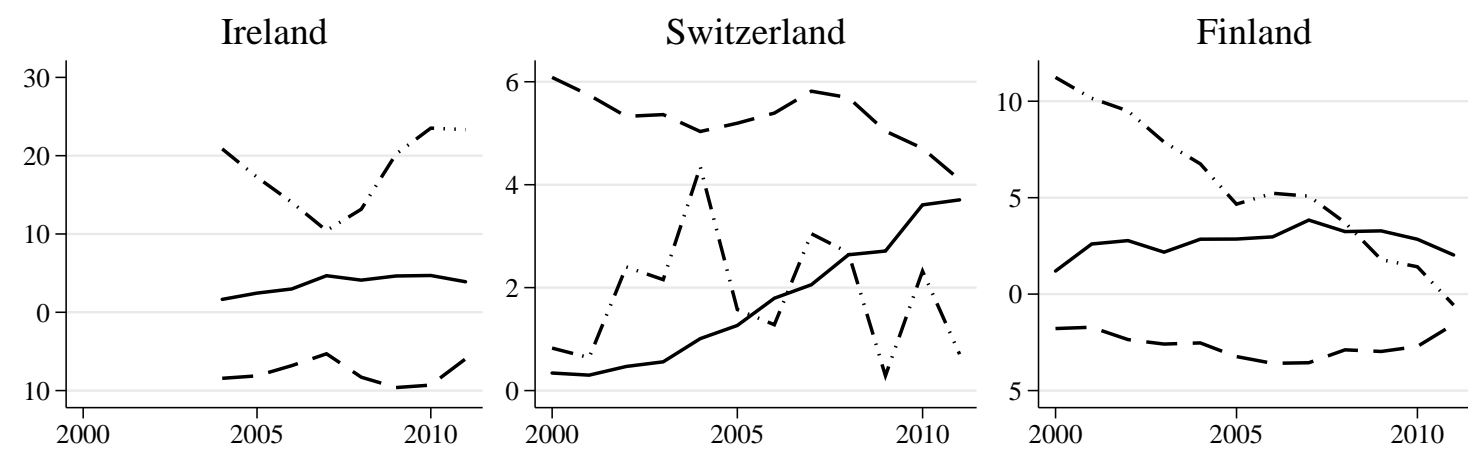

Sweden

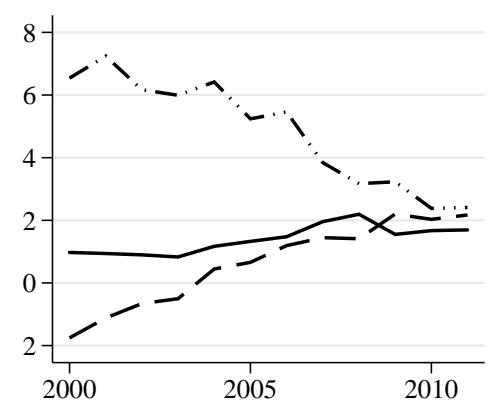

Belgium

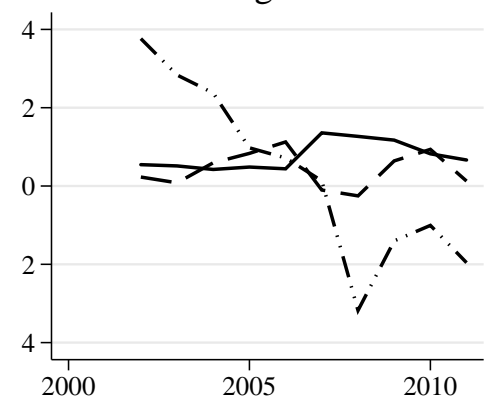

Netherlands

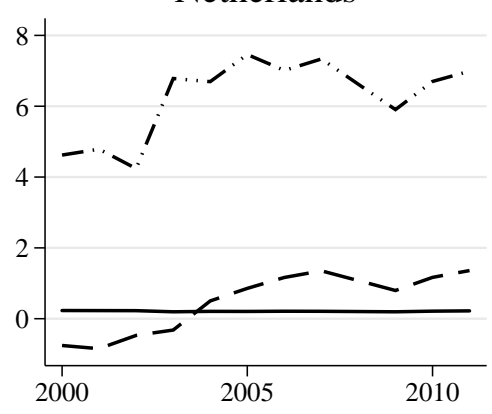

Hungary

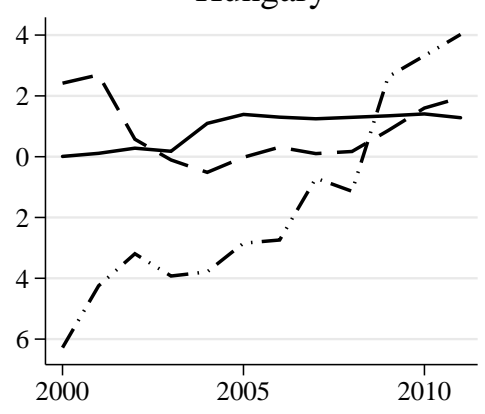

Denmark

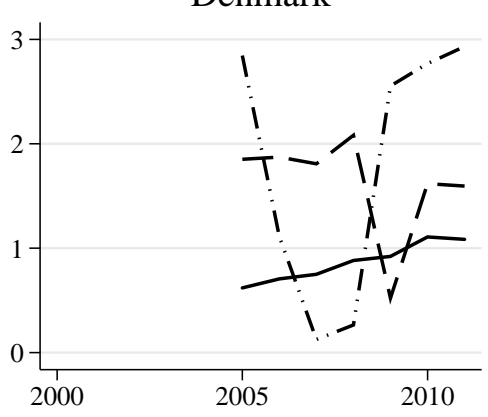

Malaysia

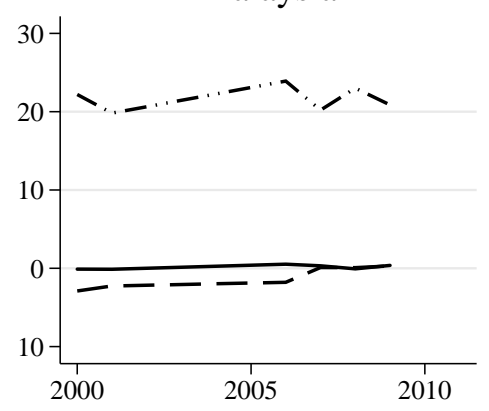

Austria

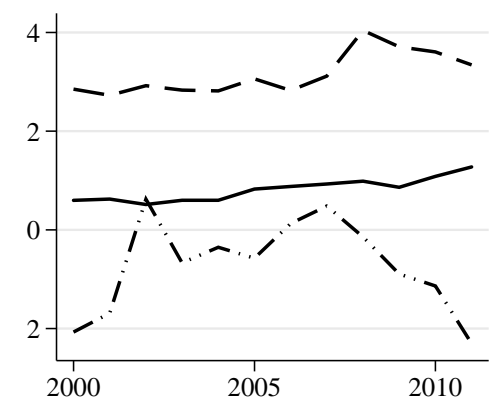

Germany

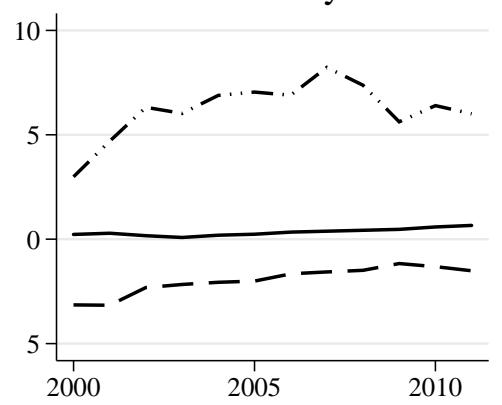

France

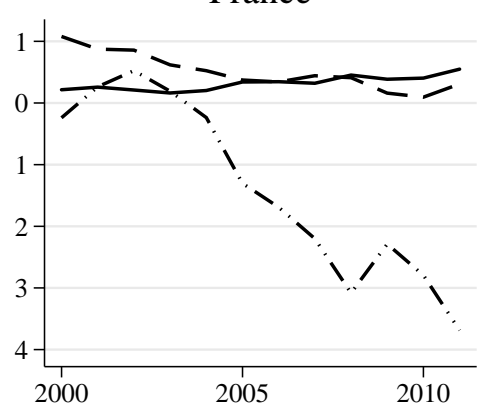

- Merchanting

- - - Trade in services (excl. merchanting)

- - $"$ Trade in goods

Source: IMF BOPS, national institutions, WDI 


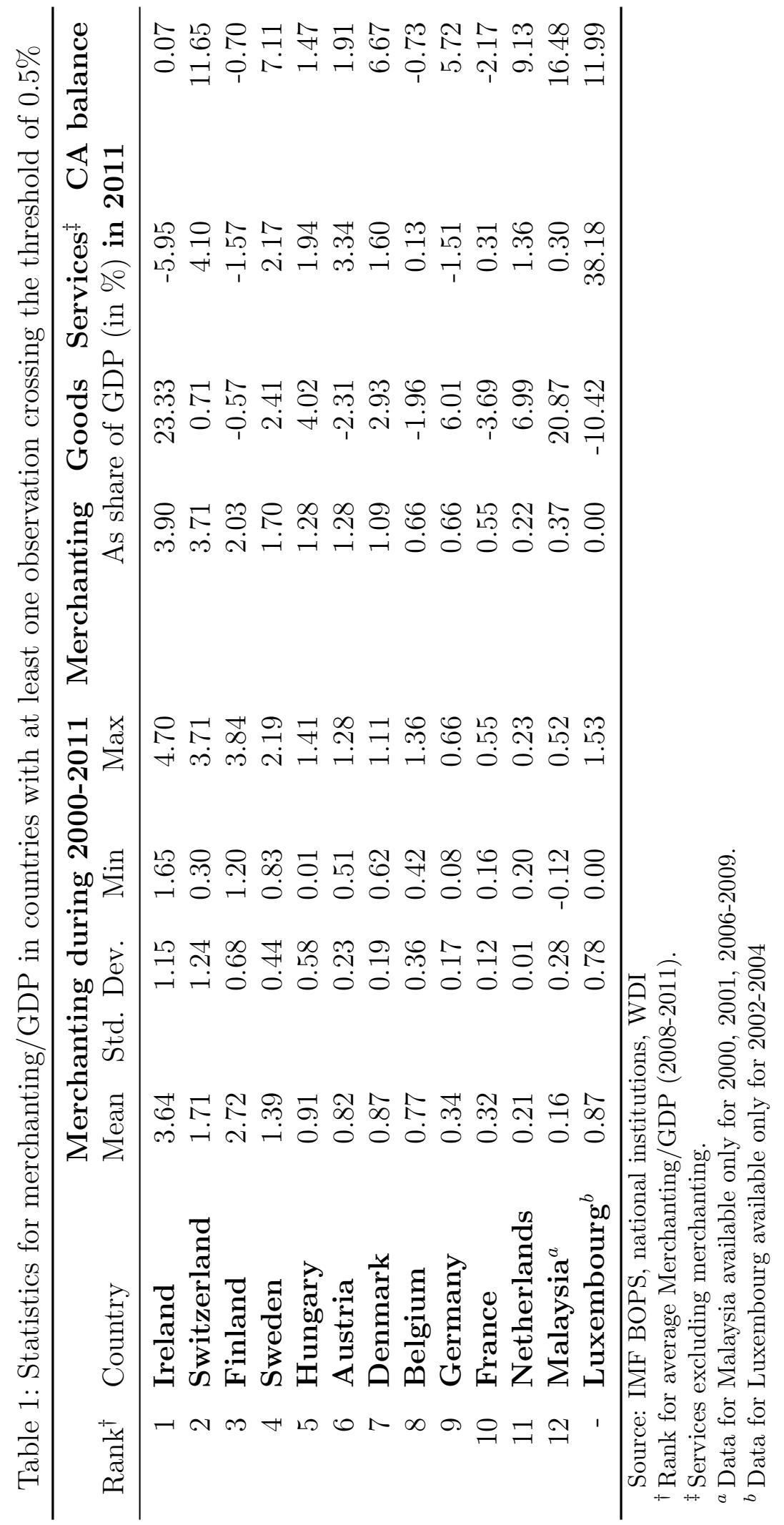


Table 2: $\mathrm{AR}(1)$ regression

\begin{tabular}{|c|c|c|c|}
\hline Dependent variables ${ }^{\star}$ : & Merchanting $^{\dagger}$ & Services ${ }^{\ddagger}$ & Goods \\
\hline \multirow[t]{2}{*}{ Own lag } & $0.83^{* * *}$ & $0.79^{* * *}$ & $0.72^{* * *}$ \\
\hline & {$[0.02]$} & {$[0.03]$} & {$[0.03]$} \\
\hline \multirow[t]{2}{*}{ Dummy for 2008} & -0.00 & $-0.00^{*}$ & $-0.01^{*}$ \\
\hline & {$[0.00]$} & {$[0.00]$} & {$[0.00]$} \\
\hline \multirow[t]{2}{*}{ Dummy for 2009} & -0.00 & $-0.00 * *$ & $0.01^{* * *}$ \\
\hline & {$[0.00]$} & {$[0.00]$} & {$[0.00]$} \\
\hline \multirow[t]{2}{*}{ Time variable } & $0.00 * * *$ & $0.00^{* *}$ & 0.00 \\
\hline & {$[0.00]$} & {$[0.00]$} & {$[0.00]$} \\
\hline \multirow[t]{2}{*}{ Constant } & -0.00 & -0.00 & -0.00 \\
\hline & {$[0.00]$} & {$[0.00]$} & {$[0.00]$} \\
\hline Observations & 585 & 585 & 585 \\
\hline Countries & 38 & 38 & 38 \\
\hline$R^{2}$ & 0.768 & 0.632 & 0.525 \\
\hline$R^{2}$ overall & 0.924 & 0.968 & 0.925 \\
\hline$R^{2}$ between & 0.966 & 0.998 & 0.994 \\
\hline
\end{tabular}

Standard errors in brackets

${ }^{* * *} \mathrm{p}<0.01,{ }^{* *} \mathrm{p}<0.05,{ }^{*} \mathrm{p}<0.1$

* Variables all as ratio to GDP (WDI), annual data (1980-2011)

$\dagger$ The backbone of the underlying data is from the IMF BOPS. Data

for merchanting is included/extended from national sources for

Australia, Brazil, Denmark, Finland, Japan, Korea, Netherlands,

New Zealand, Slovenia, Sweden, and Switzerland.

¥ Services excluding merchanting.

Table 3: Variance of residuals from AR(1) regressions

\begin{tabular}{lccc}
\hline Variance of residuals & $2000-2007$ & $2008-2011$ & $2000-2011$ \\
\hline Merchanting & 0.0000 & 0.0000 & 0.0000 \\
Trade in services ${ }^{\dagger}$ & 0.0001 & 0.0006 & 0.0001 \\
Trade in goods & 0.0004 & 0.0028 & 0.0005 \\
\hline
\end{tabular}

${ }^{\dagger}$ Services excluding merchanting.

Residuals are from the regressions shown in Table 2. 
Table 4: Baseline CA Regressions (1980-2011)

\begin{tabular}{|c|c|c|c|c|c|c|}
\hline VARIABLES & 1 & 2 & 3 & 4 & 5 & 6 \\
\hline Fiscal balance & $\begin{array}{l}0.27^{* * *} \\
{[0.09]}\end{array}$ & $\begin{array}{l}0.26^{* * *} \\
{[0.09]}\end{array}$ & $\begin{array}{l}0.26^{* * *} \\
{[0.09]}\end{array}$ & $\begin{array}{l}0.24^{* * *} \\
{[0.09]}\end{array}$ & $\begin{array}{l}0.22^{* * *} \\
{[0.08]}\end{array}$ & $\begin{array}{l}0.21^{* *} \\
{[0.08]}\end{array}$ \\
\hline Old age dependency ratio & $\begin{array}{l}-0.10 \\
{[0.07]}\end{array}$ & $\begin{array}{l}-0.10 \\
{[0.07]}\end{array}$ & $\begin{array}{l}-0.05 \\
{[0.07]}\end{array}$ & $\begin{array}{l}-0.05 \\
{[0.06]}\end{array}$ & $\begin{array}{l}0.02 \\
{[0.07]}\end{array}$ & $\begin{array}{l}0.01 \\
{[0.06]}\end{array}$ \\
\hline Population growth & $\begin{array}{l}0.07 \\
{[0.75]}\end{array}$ & $\begin{array}{l}0.14 \\
{[0.79]}\end{array}$ & $\begin{array}{l}0.17 \\
{[0.72]}\end{array}$ & $\begin{array}{l}0.25 \\
{[0.75]}\end{array}$ & $\begin{array}{l}0.49 \\
{[0.72]}\end{array}$ & $\begin{array}{l}0.55 \\
{[0.76]}\end{array}$ \\
\hline Initial NFA & $\begin{array}{l}0.06^{* * *} \\
{[0.01]}\end{array}$ & $\begin{array}{l}0.06^{* * *} \\
{[0.01]}\end{array}$ & $\begin{array}{l}0.05^{* * *} \\
{[0.01]}\end{array}$ & $\begin{array}{l}0.05^{* * *} \\
{[0.01]}\end{array}$ & $\begin{array}{l}0.03^{* *} \\
{[0.01]}\end{array}$ & $\begin{array}{l}0.03^{* * *} \\
{[0.01]}\end{array}$ \\
\hline Oil balance, Norway & $\begin{array}{l}0.18^{* *} \\
{[0.08]}\end{array}$ & $\begin{array}{l}0.24^{* * *} \\
{[0.08]}\end{array}$ & $\begin{array}{l}0.17^{* *} \\
{[0.08]}\end{array}$ & $\begin{array}{l}0.24^{* * *} \\
{[0.08]}\end{array}$ & $\begin{array}{l}0.27^{* * *} \\
{[0.08]}\end{array}$ & $\begin{array}{l}0.32^{* * *} \\
{[0.08]}\end{array}$ \\
\hline Oil balance, rest & $\begin{array}{l}0.21^{* * *} \\
{[0.04]}\end{array}$ & $\begin{array}{l}0.21^{* * *} \\
{[0.04]}\end{array}$ & $\begin{array}{l}0.27^{* * *} \\
{[0.04]}\end{array}$ & $\begin{array}{l}0.27^{* * *} \\
{[0.04]}\end{array}$ & $\begin{array}{l}0.30 * * * \\
{[0.04]}\end{array}$ & $\begin{array}{l}0.30^{* * *} \\
{[0.04]}\end{array}$ \\
\hline Output growth & $\begin{array}{l}0.09 \\
{[0.17]}\end{array}$ & $\begin{array}{l}0.10 \\
{[0.16]}\end{array}$ & $\begin{array}{l}0.11 \\
{[0.15]}\end{array}$ & $\begin{array}{l}0.13 \\
{[0.15]}\end{array}$ & $\begin{array}{l}0.13 \\
{[0.15]}\end{array}$ & $\begin{array}{l}0.14 \\
{[0.15]}\end{array}$ \\
\hline Relative income & $\begin{array}{l}0.02 \\
{[0.01]}\end{array}$ & $\begin{array}{l}0.01 \\
{[0.01]}\end{array}$ & $\begin{array}{l}0.03^{* *} \\
{[0.01]}\end{array}$ & $\begin{array}{l}0.02 \\
{[0.01]}\end{array}$ & $\begin{array}{l}0.02 \\
{[0.01]}\end{array}$ & $\begin{array}{l}0.01 \\
{[0.01]}\end{array}$ \\
\hline Banking crisis dummy & & & & & $\begin{array}{l}-0.00 \\
{[0.01]}\end{array}$ & $\begin{array}{l}-0.01 \\
{[0.00]}\end{array}$ \\
\hline Asian crisis dummy & & & $\begin{array}{l}0.05^{* * *} \\
{[0.01]}\end{array}$ & $\begin{array}{l}0.05^{* * *} \\
{[0.01]}\end{array}$ & $\begin{array}{l}0.05^{* * *} \\
{[0.01]}\end{array}$ & $\begin{array}{l}0.05^{* * *} \\
{[0.01]}\end{array}$ \\
\hline Financial centre dummy & & & & & $\begin{array}{l}0.03^{* *} \\
{[0.01]}\end{array}$ & $\begin{array}{l}0.03 \\
{[0.02]}\end{array}$ \\
\hline Euro introduction dummy: Germany & & & & & $\begin{array}{l}0.02^{*} \\
{[0.01]}\end{array}$ & $\begin{array}{l}0.01 \\
{[0.01]}\end{array}$ \\
\hline Euro introduction dummy: Periphery & & & & & $\begin{array}{l}-0.04^{* * *} \\
{[0.01]}\end{array}$ & $\begin{array}{l}-0.04^{* * *} \\
{[0.01]}\end{array}$ \\
\hline Aging society dummy & & & & & $\begin{array}{l}0.01 \\
{[0.01]}\end{array}$ & $\begin{array}{l}0.02 \\
{[0.01]}\end{array}$ \\
\hline Merchanting/GDP $>0.5 \%$ & & $\begin{array}{l}0.03 * * * \\
{[0.01]}\end{array}$ & & $\begin{array}{l}0.04^{* * * *} \\
{[0.01]}\end{array}$ & & $\begin{array}{l}0.03^{* * *} \\
{[0.01]}\end{array}$ \\
\hline Constant & $\begin{array}{l}-0.00 \\
{[0.01]}\end{array}$ & $\begin{array}{l}0.00 \\
{[0.01]}\end{array}$ & $\begin{array}{l}-0.01 \\
{[0.01]}\end{array}$ & $\begin{array}{l}-0.01 \\
{[0.01]}\end{array}$ & $\begin{array}{l}-0.01 \\
{[0.01]}\end{array}$ & $\begin{array}{l}-0.01 \\
{[0.01]}\end{array}$ \\
\hline $\begin{array}{l}\text { Observations } \\
R^{2}\end{array}$ & $\begin{array}{l}287 \\
0.566\end{array}$ & $\begin{array}{l}287 \\
0.599\end{array}$ & $\begin{array}{l}287 \\
0.624\end{array}$ & $\begin{array}{l}287 \\
0.658\end{array}$ & $\begin{array}{l}287 \\
0.668\end{array}$ & $\begin{array}{l}287 \\
0.696\end{array}$ \\
\hline
\end{tabular}

Robust standard errors in brackets

${ }^{* * *} \mathrm{p}<0.01,{ }^{* *} \mathrm{p}<0.05,{ }^{*} \mathrm{p}<0.1$

Note: Sample includes years 1980-2011; four year averages; dependent variable is the CA/GDP ratio.

See Appendix for variable definitions. 
Table 5: Comparative CA regressions (1980-2007)

\begin{tabular}{|c|c|c|c|c|c|c|}
\hline \multirow[b]{3}{*}{ VARIABLES } & \multicolumn{3}{|c|}{ initial NFA (1 to 3 ) } & \multicolumn{3}{|c|}{ lagged CA (4 to 6$)$} \\
\hline & \multicolumn{2}{|c|}{ own estimates } & \multirow{2}{*}{$\begin{array}{l}\text { IMF } \\
3\end{array}$} & \multicolumn{2}{|c|}{ own estimates } & \multirow{2}{*}{$\begin{array}{l}\text { IMF } \\
6\end{array}$} \\
\hline & 1 & 2 & & 4 & 5 & \\
\hline \multirow[t]{2}{*}{ Fiscal balance } & $0.21^{* *}$ & $0.21^{* *}$ & $0.20 * * *$ & 0.04 & 0.04 & $0.19^{* * *}$ \\
\hline & {$[0.08]$} & {$[0.08]$} & & {$[0.07]$} & {$[0.08]$} & \\
\hline \multirow[t]{2}{*}{ Old age dependency ratio } & -0.05 & -0.06 & $-0.14^{* *}$ & 0.01 & 0.01 & $-0.12^{* *}$ \\
\hline & {$[0.07]$} & {$[0.07]$} & & {$[0.05]$} & {$[0.05]$} & \\
\hline \multirow[t]{2}{*}{ Population growth } & -0.26 & -0.18 & $-1.21^{* * *}$ & -0.09 & -0.05 & -1.03 \\
\hline & {$[0.71]$} & {$[0.75]$} & & {$[0.62]$} & {$[0.65]$} & \\
\hline \multirow[t]{2}{*}{ Initial NFA } & $0.04^{* * *}$ & $0.04^{* * *}$ & $0.02^{* * *}$ & & & \\
\hline & {$[0.01]$} & {$[0.01]$} & & & & \\
\hline \multirow[t]{2}{*}{ Lagged CA } & & & & $0.67 * * *$ & $0.64^{* * *}$ & $0.37^{* * *}$ \\
\hline & & & & {$[0.06]$} & {$[0.06]$} & \\
\hline \multirow[t]{2}{*}{ Oil balance, Norway } & $0.28 * * *$ & $0.33^{* * *}$ & & $0.25^{* * *}$ & $0.28^{* * *}$ & \\
\hline & {$[0.08]$} & {$[0.08]$} & & {$[0.06]$} & {$[0.06]$} & \\
\hline \multirow[t]{2}{*}{ Oil balance, rest } & $0.33^{* * *}$ & $0.33^{* * *}$ & $0.23^{* * *}$ & $0.19^{* * *}$ & $0.20 * * *$ & $0.17^{* * *}$ \\
\hline & {$[0.05]$} & {$[0.04]$} & & {$[0.04]$} & {$[0.04]$} & \\
\hline \multirow[t]{2}{*}{ Output growth } & 0.07 & 0.09 & $-0.21^{* *}$ & -0.11 & -0.08 & $-0.16^{*}$ \\
\hline & {$[0.14]$} & {$[0.14]$} & & {$[0.13]$} & {$[0.12]$} & \\
\hline \multirow[t]{2}{*}{ Relative income } & 0.01 & 0.00 & $0.02 *$ & -0.00 & -0.00 & $0.02 *$ \\
\hline & {$[0.01]$} & {$[0.01]$} & & {$[0.01]$} & {$[0.01]$} & \\
\hline \multirow[t]{2}{*}{ Banking crisis dummy } & $-0.01^{*}$ & -0.01 & $0.01^{*}$ & $-0.01^{*}$ & -0.01 & 0.01 \\
\hline & {$[0.01]$} & {$[0.01]$} & & {$[0.00]$} & {$[0.00]$} & \\
\hline \multirow[t]{2}{*}{ Asian crisis dummy } & $0.04^{* * *}$ & $0.04^{* * *}$ & $0.06^{* * *}$ & $0.03^{* * *}$ & $0.03^{* * *}$ & $0.04^{* * *}$ \\
\hline & {$[0.01]$} & {$[0.01]$} & & {$[0.01]$} & {$[0.01]$} & \\
\hline \multirow[t]{2}{*}{ Financial centre dummy } & $0.03^{* *}$ & $0.03^{*}$ & $0.03^{* * *}$ & $0.04^{* * *}$ & $0.04^{* * *}$ & $0.03^{* * *}$ \\
\hline & {$[0.01]$} & {$[0.02]$} & & {$[0.01]$} & {$[0.01]$} & \\
\hline \multirow[t]{2}{*}{ Euro introduction dummy } & $0.01^{*}$ & 0.01 & & $0.02^{* *}$ & $0.01^{* *}$ & \\
\hline & {$[0.01]$} & {$[0.01]$} & & {$[0.01]$} & {$[0.01]$} & \\
\hline \multirow[t]{2}{*}{ Aging society dummy } & 0.01 & 0.02 & & 0.01 & 0.01 & \\
\hline & {$[0.01]$} & {$[0.01]$} & & {$[0.01]$} & {$[0.01]$} & \\
\hline \multirow[t]{2}{*}{ Merchanting/GDP $>\mathbf{0 . 5 \%}$} & & $0.03^{* *}$ & & & $0.01 * *$ & \\
\hline & & {$[0.01]$} & & & {$[0.01]$} & \\
\hline \multirow[t]{2}{*}{ Constant } & -0.01 & -0.01 & & -0.00 & -0.00 & \\
\hline & {$[0.01]$} & {$[0.01]$} & & {$[0.01]$} & {$[0.01]$} & \\
\hline Observations & 234 & 234 & & 220 & 220 & \\
\hline$R^{2}$ & 0.649 & 0.677 & 0.52 & 0.737 & 0.742 & 0.56 \\
\hline
\end{tabular}

Robust standard errors in brackets

$* * * \mathrm{p}<0.01, * * \mathrm{p}<0.05, * \mathrm{p}<0.1$

Note: Sample includes years 1980-2007; four year averages; dependent variable is the CA/GDP ratio. 
Table 6: Robustness of merchanting countries

\begin{tabular}{|c|c|c|c|c|c|c|}
\hline VARIABLES & 1 & 2 & 3 & 4 & 5 & 6 \\
\hline Fiscal balance & $\begin{array}{l}0.22^{* * *} \\
{[0.08]}\end{array}$ & $\begin{array}{l}0.23^{* * *} \\
{[0.08]}\end{array}$ & $\begin{array}{l}0.23^{* * *} \\
{[0.08]}\end{array}$ & $\begin{array}{l}0.21^{* *} \\
{[0.08]}\end{array}$ & $\begin{array}{l}0.22^{* * *} \\
{[0.08]}\end{array}$ & $\begin{array}{l}0.22^{* * *} \\
{[0.08]}\end{array}$ \\
\hline Old age dependency ratio & $\begin{array}{l}0.02 \\
{[0.07]}\end{array}$ & $\begin{array}{l}0.02 \\
{[0.07]}\end{array}$ & $\begin{array}{l}0.02 \\
{[0.07]}\end{array}$ & $\begin{array}{l}0.01 \\
{[0.06]}\end{array}$ & $\begin{array}{l}0.02 \\
{[0.06]}\end{array}$ & $\begin{array}{l}0.02 \\
{[0.07]}\end{array}$ \\
\hline Population growth & $\begin{array}{l}0.49 \\
{[0.73]}\end{array}$ & $\begin{array}{l}0.53 \\
{[0.72]}\end{array}$ & $\begin{array}{l}0.53 \\
{[0.72]}\end{array}$ & $\begin{array}{l}0.55 \\
{[0.76]}\end{array}$ & $\begin{array}{l}0.54 \\
{[0.74]}\end{array}$ & $\begin{array}{l}0.43 \\
{[0.74]}\end{array}$ \\
\hline Initial NFA & $\begin{array}{l}0.03^{* *} \\
{[0.01]}\end{array}$ & $\begin{array}{l}0.03^{* *} \\
{[0.01]}\end{array}$ & $\begin{array}{l}0.03^{* *} \\
{[0.01]}\end{array}$ & $\begin{array}{l}0.03^{* * *} \\
{[0.01]}\end{array}$ & $\begin{array}{l}0.03^{* *} \\
{[0.01]}\end{array}$ & $\begin{array}{l}0.03^{* *} \\
{[0.01]}\end{array}$ \\
\hline Oil balance, Norway & $\begin{array}{l}0.27^{* * *} \\
{[0.08]}\end{array}$ & $\begin{array}{l}0.27^{* * *} \\
{[0.08]}\end{array}$ & $\begin{array}{l}0.27^{* * *} \\
{[0.08]}\end{array}$ & $\begin{array}{l}0.32^{* * *} \\
{[0.08]}\end{array}$ & $\begin{array}{l}0.30^{* * *} \\
{[0.08]}\end{array}$ & $\begin{array}{l}0.29^{* * *} \\
{[0.08]}\end{array}$ \\
\hline Oil balance, rest & $\begin{array}{l}0.30^{* * *} \\
{[0.05]}\end{array}$ & $\begin{array}{l}0.30^{* * *} \\
{[0.04]}\end{array}$ & $\begin{array}{l}0.30 * * * \\
{[0.05]}\end{array}$ & $\begin{array}{l}0.30^{* * *} \\
{[0.04]}\end{array}$ & $\begin{array}{l}0.30^{* * *} \\
{[0.04]}\end{array}$ & $\begin{array}{l}0.30^{* * *} \\
{[0.04]}\end{array}$ \\
\hline Output growth & $\begin{array}{l}0.13 \\
{[0.15]}\end{array}$ & $\begin{array}{l}0.13 \\
{[0.15]}\end{array}$ & $\begin{array}{l}0.13 \\
{[0.15]}\end{array}$ & $\begin{array}{l}0.14 \\
{[0.15]}\end{array}$ & $\begin{array}{l}0.13 \\
{[0.15]}\end{array}$ & $\begin{array}{l}0.13 \\
{[0.16]}\end{array}$ \\
\hline Relative income & $\begin{array}{l}0.02 \\
{[0.01]}\end{array}$ & $\begin{array}{l}0.02 \\
{[0.01]}\end{array}$ & $\begin{array}{l}0.02 \\
{[0.01]}\end{array}$ & $\begin{array}{l}0.01 \\
{[0.01]}\end{array}$ & $\begin{array}{l}0.01 \\
{[0.01]}\end{array}$ & $\begin{array}{l}0.01 \\
{[0.01]}\end{array}$ \\
\hline Banking crisis dummy & $\begin{array}{l}-0.00 \\
{[0.01]}\end{array}$ & $\begin{array}{l}-0.00 \\
{[0.01]}\end{array}$ & $\begin{array}{l}-0.00 \\
{[0.01]}\end{array}$ & $\begin{array}{l}-0.01 \\
{[0.00]}\end{array}$ & $\begin{array}{l}-0.01 \\
{[0.01]}\end{array}$ & $\begin{array}{l}-0.00 \\
{[0.01]}\end{array}$ \\
\hline Asian crisis dummy & $\begin{array}{l}0.05^{* * *} \\
{[0.01]}\end{array}$ & $\begin{array}{l}0.05^{* * *} \\
{[0.01]}\end{array}$ & $\begin{array}{l}0.05^{* * *} \\
{[0.01]}\end{array}$ & $\begin{array}{l}0.05^{* * *} \\
{[0.01]}\end{array}$ & $\begin{array}{l}0.05^{* * *} \\
{[0.01]}\end{array}$ & $\begin{array}{l}0.05^{* * *} \\
{[0.01]}\end{array}$ \\
\hline Financial centre dummy & $\begin{array}{l}0.03^{* *} \\
{[0.01]}\end{array}$ & $\begin{array}{l}0.03^{* *} \\
{[0.01]}\end{array}$ & $\begin{array}{l}0.03^{* *} \\
{[0.01]}\end{array}$ & $\begin{array}{l}0.03 \\
{[0.02]}\end{array}$ & $\begin{array}{l}0.03^{*} \\
{[0.02]}\end{array}$ & $\begin{array}{l}0.03^{* *} \\
{[0.01]}\end{array}$ \\
\hline $\begin{array}{l}\text { Euro introduction dummy: } \\
\text { Germany }\end{array}$ & $0.02^{*}$ & $0.02 *$ & $0.02^{*}$ & 0.01 & $0.02 *$ & $0.02^{* *}$ \\
\hline $\begin{array}{l}\text { Euro introduction dummy: } \\
\text { Periphery }\end{array}$ & $\begin{array}{l}{[0.01]} \\
-0.04 * * *\end{array}$ & $\begin{array}{l}{[0.01]} \\
-0.04^{* * *}\end{array}$ & $\begin{array}{l}{[0.01]} \\
-0.04^{* * *}\end{array}$ & $\begin{array}{l}{[0.01]} \\
-0.04^{* * *}\end{array}$ & $\begin{array}{l}{[0.01]} \\
-0.04^{* * *}\end{array}$ & $\begin{array}{l}{[0.01]} \\
-0.04^{* * *}\end{array}$ \\
\hline Aging society dummy & $\begin{array}{l}{[0.01]} \\
0.01 \\
{[0.01]}\end{array}$ & $\begin{array}{l}{[0.01]} \\
0.02 \\
{[0.01]}\end{array}$ & $\begin{array}{l}{[0.01]} \\
0.01 \\
{[0.01]}\end{array}$ & $\begin{array}{l}{[0.01]} \\
0.02 \\
{[0.01]}\end{array}$ & $\begin{array}{l}{[0.01]} \\
0.02 \\
{[0.01]}\end{array}$ & $\begin{array}{l}{[0.01]} \\
0.01 \\
{[0.01]}\end{array}$ \\
\hline Merchanting/GDP $>0$ & $\begin{array}{l}0.00 \\
{[0.01]}\end{array}$ & & $\begin{array}{l}0.00 \\
{[0.01]}\end{array}$ & & & \\
\hline Merchanting/GDP $<0$ & & $\begin{array}{l}0.00 \\
{[0.01]}\end{array}$ & $\begin{array}{l}0.00 \\
{[0.01]}\end{array}$ & & & \\
\hline Merchanting/GDP $>0.5 \%$ & & & & $\begin{array}{l}0.03 * * * \\
{[0.01]}\end{array}$ & & \\
\hline Merchanting/GDP>1\% & & & & & $\begin{array}{l}0.03^{* * *} \\
{[0.01]}\end{array}$ & \\
\hline Merchanting/GDP $>2 \%$ & & & & & & $\begin{array}{l}0.04^{* *} \\
{[0.01]}\end{array}$ \\
\hline Constant & $\begin{array}{l}-0.01 \\
{[0.01]}\end{array}$ & $\begin{array}{l}-0.01 \\
{[0.01]}\end{array}$ & $\begin{array}{l}-0.01 \\
{[0.01]}\end{array}$ & $\begin{array}{l}-0.01 \\
{[0.01]}\end{array}$ & $\begin{array}{l}-0.01 \\
{[0.01]}\end{array}$ & $\begin{array}{l}-0.01 \\
{[0.01]}\end{array}$ \\
\hline $\begin{array}{l}\text { Observations } \\
R^{2}\end{array}$ & $\begin{array}{l}287 \\
0.669\end{array}$ & $\begin{array}{l}287 \\
0.669\end{array}$ & $\begin{array}{l}287 \\
0.669\end{array}$ & $\begin{array}{l}287 \\
0.696\end{array}$ & $\begin{array}{l}287 \\
0.686\end{array}$ & $\begin{array}{l}287 \\
0.681\end{array}$ \\
\hline
\end{tabular}

Robust standard errors in brackets

*** $\mathrm{p}<0.01,{ }^{* *} \mathrm{p}<0.05,{ }^{*} \mathrm{p}<0.1$

Note: Sample includes years 1980-2011; four year averages; dependent variable is the CA/GDP ratio. 
Table 7: Relocation of merchanting activity in 2004

\begin{tabular}{|c|c|c|c|c|c|c|}
\hline \multirow[b]{3}{*}{ VARIABLES } & & & \multicolumn{4}{|c|}{ Relocation } \\
\hline & \multicolumn{2}{|c|}{ Benchmark } & \multicolumn{2}{|c|}{ to the USA } & \multicolumn{2}{|c|}{ to Singapore } \\
\hline & 1 & 2 & 3 & 4 & 5 & 6 \\
\hline Fiscal balance & $\begin{array}{l}0.22^{* * *} \\
{[0.08]}\end{array}$ & $\begin{array}{l}0.21^{* *} \\
{[0.08]}\end{array}$ & $\begin{array}{l}0.23^{* * *} \\
{[0.08]}\end{array}$ & $\begin{array}{l}0.23^{* * *} \\
{[0.08]}\end{array}$ & $\begin{array}{l}0.23^{* * *} \\
{[0.07]}\end{array}$ & $\begin{array}{l}0.21^{* * *} \\
{[0.07]}\end{array}$ \\
\hline Old age dependency ratio & $\begin{array}{l}0.02 \\
{[0.07]}\end{array}$ & $\begin{array}{l}0.01 \\
{[0.06]}\end{array}$ & $\begin{array}{l}0.02 \\
{[0.07]}\end{array}$ & $\begin{array}{l}0.02 \\
{[0.06]}\end{array}$ & $\begin{array}{l}0.01 \\
{[0.07]}\end{array}$ & $\begin{array}{l}0.00 \\
{[0.07]}\end{array}$ \\
\hline Population growth & $\begin{array}{l}0.49 \\
{[0.72]}\end{array}$ & $\begin{array}{l}0.55 \\
{[0.76]}\end{array}$ & $\begin{array}{l}0.48 \\
{[0.73]}\end{array}$ & $\begin{array}{l}0.53 \\
{[0.73]}\end{array}$ & $\begin{array}{l}1.68 \\
{[1.37]}\end{array}$ & $\begin{array}{l}1.49 \\
{[1.18]}\end{array}$ \\
\hline Initial NFA & $\begin{array}{l}0.03^{* *} \\
{[0.01]}\end{array}$ & $\begin{array}{l}0.03^{* * *} \\
{[0.01]}\end{array}$ & $\begin{array}{l}0.03^{* *} \\
{[0.01]}\end{array}$ & $\begin{array}{l}0.03^{* *} \\
{[0.01]}\end{array}$ & $\begin{array}{l}0.03^{*} \\
{[0.01]}\end{array}$ & $\begin{array}{l}0.03^{* *} \\
{[0.01]}\end{array}$ \\
\hline Oil balance, Norway & $\begin{array}{l}0.27^{* * *} \\
{[0.08]}\end{array}$ & $\begin{array}{l}0.32^{* * *} \\
{[0.08]}\end{array}$ & $\begin{array}{l}0.28^{* * *} \\
{[0.08]}\end{array}$ & $\begin{array}{l}0.30^{* * *} \\
{[0.08]}\end{array}$ & $\begin{array}{l}0.18 \\
{[0.12]}\end{array}$ & $\begin{array}{l}0.25^{* *} \\
{[0.10]}\end{array}$ \\
\hline Oil balance, rest & $\begin{array}{l}0.30^{* * *} \\
{[0.04]}\end{array}$ & $\begin{array}{l}0.30^{* * *} \\
{[0.04]}\end{array}$ & $\begin{array}{l}0.30^{* * *} \\
{[0.04]}\end{array}$ & $\begin{array}{l}0.30^{* * *} \\
{[0.04]}\end{array}$ & $\begin{array}{l}0.30^{* * *} \\
{[0.05]}\end{array}$ & $\begin{array}{l}0.30^{* * *} \\
{[0.05]}\end{array}$ \\
\hline Output growth & $\begin{array}{l}0.13 \\
{[0.15]}\end{array}$ & $\begin{array}{l}0.14 \\
{[0.15]}\end{array}$ & $\begin{array}{l}0.13 \\
{[0.15]}\end{array}$ & $\begin{array}{l}0.13 \\
{[0.15]}\end{array}$ & $\begin{array}{l}0.45 \\
{[0.28]}\end{array}$ & $\begin{array}{l}0.39^{*} \\
{[0.22]}\end{array}$ \\
\hline Relative income & $\begin{array}{l}0.02 \\
{[0.01]}\end{array}$ & $\begin{array}{l}0.01 \\
{[0.01]}\end{array}$ & $\begin{array}{l}0.01 \\
{[0.01]}\end{array}$ & $\begin{array}{l}0.01 \\
{[0.01]}\end{array}$ & $\begin{array}{l}0.05 \\
{[0.03]}\end{array}$ & $\begin{array}{l}0.03 \\
{[0.02]}\end{array}$ \\
\hline Banking crisis dummy & $\begin{array}{l}-0.00 \\
{[0.01]}\end{array}$ & $\begin{array}{l}-0.01 \\
{[0.00]}\end{array}$ & $\begin{array}{l}-0.01 \\
{[0.01]}\end{array}$ & $\begin{array}{l}-0.01 \\
{[0.01]}\end{array}$ & $\begin{array}{l}-0.00 \\
{[0.01]}\end{array}$ & $\begin{array}{l}-0.00 \\
{[0.01]}\end{array}$ \\
\hline Asian crisis dummy & $\begin{array}{l}0.05^{* * *} \\
{[0.01]}\end{array}$ & $\begin{array}{l}0.05^{* * *} \\
{[0.01]}\end{array}$ & $\begin{array}{l}0.05^{* * *} \\
{[0.01]}\end{array}$ & $\begin{array}{l}0.05^{* * *} \\
{[0.01]}\end{array}$ & $\begin{array}{l}0.06^{* * *} \\
{[0.02]}\end{array}$ & $\begin{array}{l}0.06^{* * *} \\
{[0.01]}\end{array}$ \\
\hline Financial centre dummy & $\begin{array}{l}0.03^{* *} \\
{[0.01]}\end{array}$ & $\begin{array}{l}0.03 \\
{[0.02]}\end{array}$ & $\begin{array}{l}0.03^{* *} \\
{[0.01]}\end{array}$ & $\begin{array}{l}0.03^{* *} \\
{[0.02]}\end{array}$ & $\begin{array}{l}0.03 \\
{[0.02]}\end{array}$ & $\begin{array}{l}0.02 \\
{[0.02]}\end{array}$ \\
\hline Euro introduction dummy: Germany & $\begin{array}{l}0.02^{*} \\
{[0.01]}\end{array}$ & $\begin{array}{l}0.01 \\
{[0.01]}\end{array}$ & $\begin{array}{l}0.02^{*} \\
{[0.01]}\end{array}$ & $\begin{array}{l}0.02^{*} \\
{[0.01]}\end{array}$ & $\begin{array}{l}0.02 \\
{[0.01]}\end{array}$ & $\begin{array}{l}0.02 \\
{[0.01]}\end{array}$ \\
\hline Euro introduction dummy: Periphery & $\begin{array}{l}-0.04^{* * *} \\
{[0.01]}\end{array}$ & $\begin{array}{l}-0.04^{* * *} \\
{[0.01]}\end{array}$ & $\begin{array}{l}-0.04^{* * *} \\
{[0.01]}\end{array}$ & $\begin{array}{l}-0.04^{* * *} \\
{[0.01]}\end{array}$ & $\begin{array}{l}-0.04^{* * *} \\
{[0.01]}\end{array}$ & $\begin{array}{l}-0.04^{* * *} \\
{[0.01]}\end{array}$ \\
\hline Aging society dummy & $\begin{array}{l}0.01 \\
{[0.01]}\end{array}$ & $\begin{array}{l}0.02 \\
{[0.01]}\end{array}$ & $\begin{array}{l}0.01 \\
{[0.01]}\end{array}$ & $\begin{array}{l}0.02 \\
{[0.01]}\end{array}$ & $\begin{array}{l}0.01 \\
{[0.01]}\end{array}$ & $\begin{array}{l}0.02 \\
{[0.01]}\end{array}$ \\
\hline Merchanting/GDP $>0.5 \%$ & & $\begin{array}{l}0.03^{* * *} \\
{[0.01]}\end{array}$ & & $\begin{array}{l}0.02 \\
{[0.01]}\end{array}$ & & $\begin{array}{l}0.07^{*} \\
{[0.03]}\end{array}$ \\
\hline Constant & $\begin{array}{l}-0.01 \\
{[0.01]}\end{array}$ & $\begin{array}{l}-0.01 \\
{[0.01]}\end{array}$ & $\begin{array}{l}-0.01 \\
{[0.01]}\end{array}$ & $\begin{array}{l}-0.01 \\
{[0.01]}\end{array}$ & $\begin{array}{l}-0.03 \\
{[0.02]}\end{array}$ & $\begin{array}{l}-0.03^{*} \\
{[0.02]}\end{array}$ \\
\hline $\begin{array}{l}\text { Observations } \\
R^{2}\end{array}$ & 287 & 287 & 287 & 287 & 287 & 287 \\
\hline$R^{2}$ & 0.668 & 0.696 & 0.676 & 0.683 & 0.647 & 0.685 \\
\hline
\end{tabular}

Robust standard errors in brackets *** $\mathrm{p}<0.01,{ }^{* *} \mathrm{p}<0.05,{ }^{*} \mathrm{p}<0.1$ 


\section{Swiss National Bank Working Papers published since 2004:}

2004-1 Samuel Reynard: Financial Market Participation and the Apparent Instability of Money Demand

2004-2 Urs W. Birchler and Diana Hancock: What Does the Yield on Subordinated Bank Debt Measure?

2005-1 Hasan Bakhshi, Hashmat Khan and Barbara Rudolf: The Phillips curve under state-dependent pricing

2005-2 Andreas M. Fischer: On the Inadequacy of Newswire Reports for Empirical Research on Foreign Exchange Interventions

2006-1 Andreas M. Fischer: Measuring Income Elasticity for Swiss Money Demand: What do the Cantons say about Financial Innovation?

2006-2 Charlotte Christiansen and Angelo Ranaldo: Realized Bond-Stock Correlation: Macroeconomic Announcement Effects

2006-3 Martin Brown and Christian Zehnder: Credit Reporting, Relationship Banking, and Loan Repayment

2006-4 Hansjörg Lehmann and Michael Manz: The Exposure of Swiss Banks to Macroeconomic Shocks - an Empirical Investigation

2006-5 Katrin Assenmacher-Wesche and Stefan Gerlach: Money Growth, Output Gaps and Inflation at Low and High Frequency: Spectral Estimates for Switzerland

2006-6 Marlene Amstad and Andreas M. Fischer: Time-Varying Pass-Through from Import Prices to Consumer Prices: Evidence from an Event Study with Real-Time Data

2006-7 Samuel Reynard: Money and the Great Disinflation

2006-8 Urs W. Birchler and Matteo Facchinetti: Can bank supervisors rely on market data? A critical assessment from a Swiss perspective

2006-9 Petra Gerlach-Kristen: A Two-Pillar Phillips Curve for Switzerland

2006-10 Kevin J. Fox and Mathias Zurlinden: On Understanding Sources of Growth and Output Gaps for Switzerland

2006-11 Angelo Ranaldo: Intraday Market Dynamics Around Public Information Arrivals

2007-1 Andreas M. Fischer, Gulzina Isakova and Ulan Termechikov: Do FX traders in Bishkek have similar perceptions to their London colleagues? Survey evidence of market practitioners' views 
2007-2 Ibrahim Chowdhury and Andreas Schabert: Federal Reserve Policy viewed through a Money Supply Lens

2007-3 Angelo Ranaldo: Segmentation and Time-of-Day Patterns in Foreign Exchange Markets

2007-4 Jürg M. Blum: Why `Basel II' May Need a Leverage Ratio Restriction

2007-5 Samuel Reynard: Maintaining Low Inflation: Money, Interest Rates, and Policy Stance

2007-6 Rina Rosenblatt-Wisch: Loss Aversion in Aggregate Macroeconomic Time Series

2007-7 Martin Brown, Maria Rueda Maurer, Tamara Pak and Nurlanbek Tynaev: Banking Sector Reform and Interest Rates in Transition Economies: Bank-Level Evidence from Kyrgyzstan

2007-8 Hans-Jürg Büttler: An Orthogonal Polynomial Approach to Estimate the Term Structure of Interest Rates

2007-9 Raphael Auer: The Colonial Origins Of Comparative Development: Comment. A Solution to the Settler Mortality Debate

2007-10 Franziska Bignasca and Enzo Rossi: Applying the Hirose-Kamada filter to Swiss data: Output gap and exchange rate pass-through estimates

2007-11 Angelo Ranaldo and Enzo Rossi: The reaction of asset markets to Swiss National Bank communication

2007-12 Lukas Burkhard and Andreas M. Fischer: Communicating Policy Options at the Zero Bound

2007-13 Katrin Assenmacher-Wesche, Stefan Gerlach, and Toshitaka Sekine: Monetary Factors and Inflation in Japan

2007-14 Jean-Marc Natal and Nicolas Stoffels: Globalization, markups and the natural rate of interest

2007-15 Martin Brown, Tullio Jappelli and Marco Pagano: Information Sharing and Credit: Firm-Level Evidence from Transition Countries

2007-16 Andreas M. Fischer, Matthias Lutz and Manuel Wälti: Who Prices Locally? Survey Evidence of Swiss Exporters

2007-17 Angelo Ranaldo and Paul Söderlind: Safe Haven Currencies 
2008-1 Martin Brown and Christian Zehnder: The Emergence of Information Sharing in Credit Markets

2008-2 Yvan Lengwiler and Carlos Lenz: Intelligible Factors for the Yield Curve

2008-3 Katrin Assenmacher-Wesche and M. Hashem Pesaran: Forecasting the Swiss Economy Using VECX* Models: An Exercise in Forecast Combination Across Models and Observation Windows

2008-4 Maria Clara Rueda Maurer: Foreign bank entry, institutional development and credit access: firm-level evidence from 22 transition countries

2008-5 Marlene Amstad and Andreas M. Fischer: Are Weekly Inflation Forecasts Informative?

2008-6 Raphael Auer and Thomas Chaney: Cost Pass Through in a Competitive Model of Pricing-to-Market

2008-7 Martin Brown, Armin Falk and Ernst Fehr: Competition and Relational Contracts: The Role of Unemployment as a Disciplinary Device

2008-8 Raphael Auer: The Colonial and Geographic Origins of Comparative Development

2008-9 Andreas M. Fischer and Angelo Ranaldo: Does FOMC News Increase Global FX Trading?

2008-10 Charlotte Christiansen and Angelo Ranaldo: Extreme Coexceedances in New EU Member States' Stock Markets

2008-11 Barbara Rudolf and Mathias Zurlinden: Measuring capital stocks and capital services in Switzerland

2008-12 Philip Sauré: How to Use Industrial Policy to Sustain Trade Agreements

2008-13 Thomas Bolli and Mathias Zurlinden: Measuring growth of labour quality and the quality-adjusted unemployment rate in Switzerland

2008-14 Samuel Reynard: What Drives the Swiss Franc?

2008-15 Daniel Kaufmann: Price-Setting Behaviour in Switzerland - Evidence from CPI Micro Data

2008-16 Katrin Assenmacher-Wesche and Stefan Gerlach: Financial Structure and the Impact of Monetary Policy on Asset Prices

2008-17 Ernst Fehr, Martin Brown and Christian Zehnder: On Reputation: A Microfoundation of Contract Enforcement and Price Rigidity 
2008-18 Raphael Auer and Andreas M. Fischer: The Effect of Low-Wage Import Competition on U.S. Inflationary Pressure

2008-19 Christian Beer, Steven Ongena and Marcel Peter: Borrowing in Foreign Currency: Austrian Households as Carry Traders

2009-1 Thomas Bolli and Mathias Zurlinden: Measurement of labor quality growth caused by unobservable characteristics

2009-2 Martin Brown, Steven Ongena and Pinar Yeșin: Foreign Currency Borrowing by Small Firms

2009-3 Matteo Bonato, Massimiliano Caporin and Angelo Ranaldo: Forecasting realized (co)variances with a block structure Wishart autoregressive model

2009-4 Paul Söderlind: Inflation Risk Premia and Survey Evidence on Macroeconomic Uncertainty

2009-5 Christian Hott: Explaining House Price Fluctuations

2009-6 Sarah M. Lein and Eva Köberl: Capacity Utilisation, Constraints and Price Adjustments under the Microscope

2009-7 Philipp Haene and Andy Sturm: Optimal Central Counterparty Risk Management

2009-8 Christian Hott: Banks and Real Estate Prices

2009-9 Terhi Jokipii and Alistair Milne: Bank Capital Buffer and Risk Adjustment Decisions

2009-10 Philip Sauré: Bounded Love of Variety and Patterns of Trade

2009-11 Nicole Allenspach: Banking and Transparency: Is More Information Always Better?

2009-12 Philip Sauré and Hosny Zoabi: Effects of Trade on Female Labor Force Participation

2009-13 Barbara Rudolf and Mathias Zurlinden: Productivity and economic growth in Switzerland 1991-2005

2009-14 Sébastien Kraenzlin and Martin Schlegel: Bidding Behavior in the SNB's Repo Auctions

2009-15 Martin Schlegel and Sébastien Kraenzlin: Demand for Reserves and the Central Bank's Management of Interest Rates

2009-16 Carlos Lenz and Marcel Savioz: Monetary determinants of the Swiss franc 
2010-1 Charlotte Christiansen, Angelo Ranaldo and Paul Söderlind: The Time-Varying Systematic Risk of Carry Trade Strategies

2010-2 Daniel Kaufmann: The Timing of Price Changes and the Role of Heterogeneity

2010-3 Loriano Mancini, Angelo Ranaldo and Jan Wrampelmeyer: Liquidity in the Foreign Exchange Market: Measurement, Commonality, and Risk Premiums

2010-4 Samuel Reynard and Andreas Schabert: Modeling Monetary Policy

2010-5 Pierre Monnin and Terhi Jokipii: The Impact of Banking Sector Stability on the Real Economy

2010-6 Sébastien Kraenzlin and Thomas Nellen: Daytime is money

2010-7 Philip Sauré: Overreporting 0il Reserves

2010-8 Elizabeth Steiner: Estimating a stock-flow model for the Swiss housing market

2010-9 Martin Brown, Steven Ongena, Alexander Popov, and Pinar Yeșin: Who Needs Credit and Who Gets Credit in Eastern Europe?

2010-10 Jean-Pierre Danthine and André Kurmann: The Business Cycle Implications of Reciprocity in Labor Relations

2010-11 Thomas Nitschka: Momentum in stock market returns: Implications for risk premia on foreign currencies

2010-12 Petra Gerlach-Kristen and Barbara Rudolf: Macroeconomic and interest rate volatility under alternative monetary operating procedures

2010-13 Raphael Auer: Consumer Heterogeneity and the Impact of Trade Liberalization: How Representative is the Representative Agent Framework?

2010-14 Tommaso Mancini Griffoli and Angelo Ranaldo: Limits to arbitrage during the crisis: funding liquidity constraints and covered interest parity

2010-15 Jean-Marc Natal: Monetary Policy Response to Oil Price Shocks

2010-16 Kathrin Degen and Andreas M. Fischer: Immigration and Swiss House Prices

2010-17 Andreas M. Fischer: Immigration and large banknotes

2010-18 Raphael Auer: Are Imports from Rich Nations Deskilling Emerging Economies? Human Capital and the Dynamic Effects of Trade 
2010-19 Jean-Pierre Danthine and John B. Donaldson: Executive Compensation: A General Equilibrium Perspective

2011-1 Thorsten Beck and Martin Brown: Which Households Use Banks? Evidence from the Transition Economies

2011-2 Martin Brown, Karolin Kirschenmann and Steven Ongena: Foreign Currency Loans Demand or Supply Driven?

2011-3 Victoria Galsband and Thomas Nitschka: Foreign currency returns and systematic risks

2011-4 Francis Breedon and Angelo Ranaldo: Intraday patterns in FX returns and order flow

2011-5 Basil Guggenheim, Sébastien Kraenzlin and Silvio Schumacher: Exploring an uncharted market: Evidence on the unsecured Swiss franc money market

2011-6 Pamela Hall: Is there any evidence of a Greenspan put?

2011-7 Daniel Kaufmann and Sarah Lein: Sectoral Inflation Dynamics, Idiosyncratic Shocks and Monetary Policy

2011-8 Iva Cecchin: Mortgage Rate Pass-Through in Switzerland

2011-9 Raphael A. Auer, Kathrin Degen and Andreas M. Fischer: Low-Wage Import Competition, Inflationary Pressure, and Industry Dynamics in Europe

2011-10 Raphael A. Auer and Philip Sauré: Spatial Competition in Quality, Demand-Induced Innovation, and Schumpeterian Growth

2011-11 Massimiliano Caporin , Angelo Ranaldo and Paolo Santucci de Magistris: On the Predictability of Stock Prices: a Case for High and Low Prices

2011-12 Jürg Mägerle and Thomas Nellen: Interoperability between central counterparties

2011-13 Sylvia Kaufmann: K-state switching models with endogenous transition distributions

2011-14 Sébastien Kraenzlin and Benedikt von Scarpatetti: Bargaining Power in the Repo Market

2012-01 Raphael A. Auer: Exchange Rate Pass-Through, Domestic Competition, and Inflation: Evidence from the 2005/08 Revaluation of the Renminbi

2012-02 Signe Krogstrup, Samuel Reynard and Barbara Sutter: Liquidity Effects of Quantitative Easing on Long-Term Interest Rates 
2012-03 Matteo Bonato, Massimiliano Caporin and Angelo Ranaldo: Risk spillovers in international equity portfolios

2012-04 Thomas Nitschka: Banking sectors' international interconnectedness: Implications for consumption risk sharing in Europe

2012-05 Martin Brown, Steven Ongena and Pinar Yeşin: Information Asymmetry and Foreign Currency Borrowing by Small Firms

2012-06 Philip Sauré and Hosny Zoabi: Retirement Age across Countries: The Role of Occupations

2012-07 Christian Hott and Terhi Jokipii: Housing Bubbles and Interest Rates

2012-08 Romain Baeriswyl and Camille Cornand: Reducing overreaction to central bank's disclosures: theory and experiment

2012-09 Bo E. Honoré, Daniel Kaufmann and Sarah Lein: Asymmetries in Price-Setting Behavior: New Microeconometric Evidence from Switzerland

2012-10 Thomas Nitschka: Global and country-specific business cycle risk in time-varying excess returns on asset markets

2012-11 Raphael A. Auer, Thomas Chaney and Philip Sauré: Quality Pricing-to-Market

2012-12 Sébastien Kraenzlin and Thomas Nellen: Access policy and money market segmentation

2012-13 Andreas Kropf and Philip Sauré: Fixed Costs per Shipment

2012-14 Raphael A. Auer and Raphael S. Schoenle: Market Structure and Exchange Rate Pass-Through

2012-15 Raphael A. Auer: What Drives Target2 Balances? Evidence From a Panel Analysis

2012-16 Katja Drechsel and Rolf Scheufele: Bottom-up or Direct? Forecasting German GDP in a Data-rich Environment

2013-01 Andreas Kettemann and Signe Krogstrup: Portfolio balance effects of the SNB's bond purchase program

2013-02 Nicole Aregger, Martin Brown and Enzo Rossi: Transaction Taxes, Capital Gains Taxes and House Prices

2013-03 Simone Meier: Financial Globalization and Monetary Transmission 
2013-04 Christian Grisse and Thomas Nitschka: On financial risk and the safe haven characteristics of Swiss franc exchange rates

2013-05 Matthias Gubler and Matthias S. Hertweck: Commodity Price Shocks and the Business Cycle: Structural Evidence for the U.S.

2013-06 Elisabeth Beusch, Barbara Döbeli, Andreas Fischer and Pinar Yeșin: Merchanting and Current Account Balances 
Swiss National Bank Working Papers are also available at www.snb.ch, section Publications/Research Subscriptions or individual issues can be ordered at Swiss National Bank, Fraumünsterstrasse 8, CH-8022 Zurich, fax +41 4463181 14, E-mail library@snb.ch 